\title{
Local IPOs, local delistings, and the firm location premium
}

\author{
Giulia Baschieri ${ }^{\mathrm{a}}$, Andrea Carosi ${ }^{\mathrm{b}, *}$, Stefano Mengoli ${ }^{\mathrm{a}}$ \\ ${ }^{a}$ University of Bologna, Department of Management, 34 Via Capo di Lucca, 40126 Bologna, Italy \\ ${ }^{\mathrm{b}}$ University of Sassari, Department of Economics and Business, 25 Via Muroni, 07100 Sassari, Italy
}

\section{A R T I C L E I N F O}

Article history:

Received 13 May 2013

Accepted 17 December 2014

Available online 24 December 2014

\section{JEL classification:}

G11

G12

Keywords:

Location premium

Local home bias

IPO

Delisting

Underpricing

\begin{abstract}
A B S T R A C T
Borrowing a measure from ecology, we introduce a spatial dispersion index to quantify the firm traits related to firm geographic location and investigate firm exposure to local home bias and local investor risk tolerance as determinants of corporate market value. Consistent with the investor preference for local stocks, we find listed firms benefit from a location premium that increases with firm isolation and local investor wealth. IPOs and delistings are found to affect the market value of neighboring listed firms: isolated firms decrease in value when they cluster due to local IPOs while clustered firms increase in value as they become more isolated due to local delistings. Local firm clustering and risk tolerance also affect IPO underpricing. Empirical findings depict a framework where IPOs and delistings are locally jointly determined.
\end{abstract}

(C) 2015 Elsevier B.V. All rights reserved.

\section{Introduction}

Basic asset-allocation principles notwithstanding (e.g., Detemple et al., 2005; Farinelli et al., 2008), a disproportionately large proportion of equity portfolios is invested in geographically proximate stocks (e.g., Coval and Moskowitz, 1999; Ivković and Weisbenner, 2005). As a consequence, the firm geographic location affects corporate market value (e.g., Hong et al., 2008; Korniotis and Kumar, 2013). Given that a portion of local wealth is invested in local equity (Local Home Bias, henceforth LHB), the short supply of local stocks pushes market prices of geographically isolated firms up, and vice versa when local stocks are plentiful (the LHB effect). The value implications, when there are changes to the set of local companies available for investment, have been never addressed in the literature. We fill this gap by investigating the value implications as neighboring firms go public (local IPOs) and private (local delistings). In addition, we test whether the local supply and demand for local stocks also affect IPO underpricing. Our analysis offers improved methodology, supports the idea that firm geographic location is a non-negligible asset-pricing factor, and traces a conceptual framework whereby IPOs and delistings are locally and jointly determined.

* Corresponding author. Tel.: +39 079 213036; fax: +39 079213002.

E-mail addresses: giulia.baschieri@unibo.it (G. Baschieri), acarosi@uniss.it (A. Carosi), stefano.mengoli@unibo.it (S. Mengoli).
The LHB stems from informational advantages on local stocks (e.g., Coval and Moskowitz, 2001), though behavioral factors also come into play (e.g., Grinblatt and Keloharju, 2001), primarily affects smaller, opaque, and less recognizable firms (Coval and Moskowitz, 1999; Zhu, 2003; Ivković and Weisbenner, 2005), and is correlated with poorly-educated male individuals, especially employees in public administration with no experience in risky investments (Karlsson and Nordén, 2007). Consistent with the LHB, Hong et al. (2008) (HKS) find that the market-to-book is inversely related to the ratio of the equity book value of local listed firms (i.e., the local supply of stocks) and the disposable income of local households (i.e., the local demand for stocks). More simply, firms trade at a premium when they are headquartered in rich areas where there are few local firms available for investment.

Our analysis improves upon the HKS approach. The relation between the firm location and the market value is also addressed in this paper. First, our contribution introduces into the financial literature the Johnson and Zimmer (1985) spatial dispersion index (henceforth noted as I). Previously adopted in the ecology literature to measure the tendency of living organisms to form clusters (e.g., Gomelyuk and Shchetkov, 1999; Lee et al., 2006), we implement the I-index to proxy the firm characteristics that are related to firm geographic location. The $I$-index allows us to define a firm-specific value of clustering around the firm headquarters with respect to location-related firm attributes. We specifically consider two attributes: the location of the other listed firms (on the 
equity-market supply side) and investor wealth (on the equitymarket demand side). Our analysis attempts to define the portion of corporate market value that is attributable to the LHB, to local investor wealth, and ultimately, to firm geographic location (location premium). Most importantly, we provide evidence that variations in the location premium are caused by variations in the set of local companies. In fact, there are only three sources of variation: (i) local IPOs, causing local firms to become more clustered; (ii) local delistings, causing local firms to become more isolated; and (iii) the relocation of the headquarters, which, from a local perspective, acts as a simultaneous local IPO for the new hosting area and a local delisting for the old area. ${ }^{1}$ In line with previous findings for the LHB, we conjecture that local IPOs decrease the location premium of listed (local) firms, while local delistings have the opposite effect and increase the location premium of listed (local) firms. To provide additional results that should further support these conjectures, we test the relation between the IPO first-day return and the firm location. Firms located in areas with higher income clustering and lower concentration of local listed firms should exhibit a higher location premium and thus larger underpricing.

We analyze the Italian firms listed on the Milan Stock Exchange (MSE) over the period 1999-2007. Our results indicate that the corporate market value drops with the proximity to other listed firms and rises with the proximity to investor income; the overall location premium accounts for approximately 0.7 of the marketto-book value. We find the location premium varies due to local IPOs and delistings. We divide our sample of firms into four clusters based on their distance from the other listed firms: Cluster 1 groups the highly isolated firms, and cluster 4 groups the highly clustered firms. The aggregation effect of local IPOs decreases the value of highly isolated firms by approximately $20 \%$, while the isolation effect of local delistings increases the value of the highly clustered firms by approximately 35\%. In addition, even the IPO first-day return increases with issuing firm isolation from other listed firms and proximity to investor wealth.

Methodologically, the financial literature is improved by the Johnson and Zimmer dispersion index. Similar to living organisms, companies interact with each other and with their surrounding environment. The outcomes of these interactions are responsible for firm profitability and probability of survival. Spinoffs from ecology, which is the study of these relationships, appear to be suitable for investigating causations in corporate finance. Indeed, the Iindex of dispersion emerges as the most powerful proxy thus far for firm traits related to location. Recent research has amply investigated many firm traits related to firm location such as the effect of corporate geographic dispersion on liquidity or the cost of debt (among the first examples, see Loughran and Schultz, 2005; and later Loughran, 2008; Arena and Dewally, 2012). For instance, Loughran and Schultz (2005) distinguish urban from rural firms in their distance from the major U.S. metropolitan areas and find that rural stocks are less liquid than urban stocks. Arena and Dewally (2012) indicate that urban firms face a lower cost of debt and attract more prestigious bank syndicates than rural firms. In addition, Gao et al. (2008), Landier et al. (2009), and García and Norli (2012) investigate the effects of the corporate geographic dispersion on corporate market value, corporate decision making, and stock returns. All of these studies employed a range of proxies for corporate geographic dispersion including the number of regions where subsidiaries are located (Gao et al., 2008), the proportion of divisions in the home state (Landier et al., 2009), and even the number of states mentioned in annual reports (García and Norli, 2012). In all of these cases, companies are categorized (e.g.,

\footnotetext{
${ }^{1}$ Relocating headquarters is a very rare phenomenon. HKS find just 23 switchers, i.e., firms that moved their headquarters from one census region to another over the period 1970-2005. Similarly, we find just 13 switchers.
}

dispersed vs. nondispersed or local vs. nonlocal) using an ex ante defined threshold (e.g., regions, states, etc.) and ignoring the pattern of the location attributes outside the threshold (e.g., firms located in the neighboring regions), with obvious disadvantages in measurement accuracy. The Johnson and Zimmer dispersion index values of subsidiaries, divisions, and areas of interest should be significantly better proxies for the firm geographic dispersion because the $I$-index avoids incorporating any exogenous assumptions and is fully determined by the complete spatial distribution of the considered firm location attributes.

From the empirical standpoint, our results support the prior findings in the literature and expand the current understanding of the geographic components in price formation (e.g., Pirinsky and Wang, 2006; Arena and Dewally, 2012; García and Norli, 2012). The figures indicate that firm geographic location emerges as a non-negligible asset-pricing factor, which has an effect of the same magnitude on corporate market value as that of the ROE. In fact, even among relatively close local firms (e.g., no more than $300 \mathrm{~km}$ apart), location premium differences are not trivial (e.g., from 6\% to 8\%). Apart from the obvious implications for academics and practitioners, these findings could also have policy implications as both private and listed isolated firms are expected to gain from their "spatial status" (i.e., a large audience of "dedicated" investors): Isolated IPOs or isolated SEOs should face a lower risk of failure. In a similar vein, Korniotis and Kumar (2013) conclude that "local clientele-induced geographical segmentation implies that firms can alter their cost of capital by relocating headquarters" (Korniotis and Kumar, 2013, p. 1093). Our results on underpricing strongly support their conclusions.

Our results also contribute to the IPO and delistings literature. First, we offer new insights on the underpricing puzzle (e.g., Ritter and Welch, 2002): The higher underpricing of isolated IPOs is consistent with a myopia of actors taking part to the going public process (e.g., underwriters), who do not seem to properly take into account the LHB effect in the IPO price-setting process. Second, our findings on the asset-pricing implications of local IPOs and delistings are new to the literature and join the recent contributions by Braun and Larrain (2009), Colaco et al. (2009) and Hsu et al. (2010) whereby IPOs are investigated as an integrated phenomenon that interacts with the surrounding economic environment rather than as a stand-alone corporate event. Our results for delistings introduce this same integrated perspective into the ongoing public-to-private transactions debate (e.g., Renneboog and Simons, 2005; Renneboog et al., 2007; Baran and King, 2010; Achleitner et al., 2013; Boubakri et al., 2013; Fidrmuc et al., 2013; Croci and Del Giudice, 2014). In fact, IPOs and delistings emerge as local substitutes: The delistings of local firms would free space and extant local resources, thus increasing the success of local IPOs and vice versa. We believe there is ample room for future research.

Finally our results also contribute to the so-called agglomeration economies (e.g., Marshall, 1920; Rosenthal and Strange, 2004): Firms benefit from clustering due to external economies of scale such as the proximity to customers and suppliers (e.g., Krugman, 1991), the presence of a labor pool and infrastructures (e.g., Enright, 2003), or knowledge spillovers (e.g., Audretsch and Feldman, 1996). We provide evidence for the other side of the debate on clustering, which has been neglected thus far. In fact, the value enhancing effect of firm clustering appears to be at least partly offset by a reduction in the location premium.

The remainder of the paper is organized as follows. Section 2 illustrates the spatial dispersion indices and the empirical strategy. Section 3 provides details on data and variables. Section 4 depicts the anatomy of the implemented spatial indices. Section 5, Section 6 and Section 7 report the results. Section 8 contains robustness checks. Section 9 concludes. 


\section{The indices of spatial dispersion and the empirical strategy}

We introduce the Johnson and Zimmer (1985) spatial dispersion index ( $I$-index) as a method of capturing the firm-specific features (or attributes) related to a firm's geographic location. The $I$ index is based on point-to-point individual distances. So, given a two-dimensional Euclidean space, the generic point $i$ and a sample of other points $r$ that are determined by the geographical coordinates of latitude and longitude, the dispersion index $I$ for $i$ with respect to $r$ is computed as

$$
I=\frac{(r+1) \sum_{r=1 \& r \neq i}^{r}\left(d_{i, r}^{4}\right)}{\left[\sum_{r=1 \& r \neq i}^{r}\left(d_{i, r}^{2}\right)\right]^{2}}
$$

where $d_{i, r}$ is the shortest spherical distance between $i$ and each of the $r$ points. The expected value of I is approximately two for a random spatial distribution, lower than two for a scattered spatial distribution, and higher than two for a concentrated spatial distribution. Essentially, while clustered points exhibit I values larger than two, isolated points will have an $I$ value lower than two. Fig. 1 displays an example of a possible spatial distribution of 20 points: The previously defined value of the $I$-index determines the size of the points plotted. In this example, point A records the lowest $I$-index value (1.187), the farthest point from the other points, while point B records the highest value of $I$-index (5.340), the closest point to all other points. If we assume this example indicates firm headquarters, firm A (with the lowest $I$-index value) is isolated compared to other firm headquarters locations, while firm B (with the highest $I$-index value) is likely part of a clustered spatial distribution with other listed firms. A similar interpretation holds when the points refer to household disposable income. Therefore, the Iindex addresses firm "subjective" spatial distribution or firm-specific "spatial status".

Taking into consideration the location of the other listed firms and the location of investor wealth as two attributes of the firm location, we propose two variables: I_FIRM and I_INCOME. I_FIRM is defined by I computed on the spatial distribution of other listed firms. I_INCOME is the value of I based on the weighted distance between each firm and each provincial capital city, where weights are equal to the normalized provincial per capita household disposable income. It follows that I_INCOME measures the disposable income clustering around the firm assuming household wealth is located in the center of the province where the household resides.

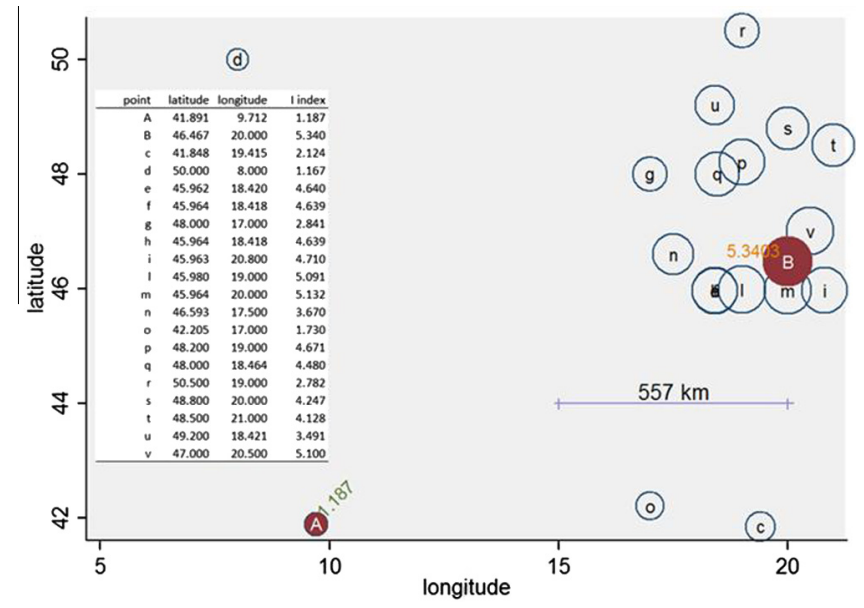

Fig. 1. The Johnson and Zimmer Spatial Dispersion Index. This figure displays the spatial distribution of 20 points according to their latitude $(y$-axis) and longitude $(x$ axis). The Johnson and Zimmer (1985) spatial dispersion index determines the size of the points plotted. Latitude, longitude, and the $I$-index value of each point are also reported in the grid.
In line with the example in Fig. 1, a higher value of I_FIRM indicates a higher concentration of listed firms around the firm headquarters. Because the local investor demand for local stocks will be divided among all of the firms in a given local area, all other things being equal, the LHB effect is expected to be low. Therefore, I_FIRM (inversely) proxies for the firm exposure to LHB. On the other hand, a high value of $I$ INCOME indicates that investor wealth is locally concentrated around the issuing firm headquarters or, more simply, that the local investors are richer than elsewhere. As in HKS and Aabo et al. (2013), we assume the local investor risk tolerance is proportional to the local wealth. Hence, I_INCOME measures the investor risk tolerance around the issuing firm headquarters.

I_FIRM and I_INCOME provide several advantages over previous measures of firm traits related to the spatial dimension (e.g., Gao et al., 2008; HKS; García and Norli, 2012). First, I_FIRM and I_INCOME do not incorporate any exogenous assumptions about locality. This is a clear advantage in cases such as Bolzoni S.p.A., a sampled firm headquartered in the northeastern region of Italy, Emilia-Romagna. For instance, using the HKS approach whereby local firms are defined as firms headquartered within the same census region, the LHB effect for Bolzoni S.p.A. would be proxied by the ratio (RATIO) of the equity book value of listed firms and the disposable income of households in Emilia-Romagna. However, Bolzoni S.p.A is an average of $121 \mathrm{~km}$ away from other firms in Emilia-Romagna but only $70 \mathrm{~km}$ (on average) away from firms headquartered in the contiguous region of Lombardy (northwestern Italy). In fact, the LHB faced by Bolzoni S.p.A. is significantly biased when estimated by the RATIO. On the other hand, the second advantage to using I_FIRM and I_INCOME is that they are fully endogenously determined by the complete spatial distributions of the related firm location attributes. For example, while RATIO is defined only for within-region firms, I_FIRM considers the spatial distribution of all sampled firms. There are some clear advantages in accurately measuring the LHB. For example, when contiguous areas with heterogeneous firm populations are addressed, the RATIO overestimates (underestimates) the LHB of the less populated (more populated) area. Similar arguments hold for I_INCOME. Finally, because I_FIRM and I_INCOME are firm-specific rather than local-specific measures, they allow for different location premiums among the local firms, while previous approaches imply the same location premium for all local firms. In addition, I_FIRM and I_INCOME allow the supply side LHB effect to be disentangled from the investor risk tolerance effect on the demand side.

We investigate the relations between the market-to-book and the firm location attributes by first proxying the location attributes through the HKS RATIO. Consistent with previous evidence, we expect to observe a negative relation between RATIO and market-to-book. Then, we introduce I_FIRM and I_INCOME. I_FIRM is expected to be inversely related to market-to-book, while I_INCOME is expected to be directly related. As per Ivković and Weisbenner (2005), we also distinguish firms in and out of the primary Italian equity market index (FTSE MIB Index, henceforth FTSE MIB), and we expect firms in the FTSE MIB to be less affected by RATIO, I_FIRM and I_INCOME than firms not in the FTSE MIB. The confirmation of this hypothesis should remove any doubt that we are actually targeting the LHB and confirm the effectiveness of $I$ _FIRM and I_INCOME.

Then, we address the dynamic aspect of the location premium by analyzing the variations induced by IPOs and delistings. Local IPOs increase the set of local companies available for investment, leaving the portion of investor portfolio invested in local stocks unchanged. Therefore, all other things being equal, we expect that due to local IPOs, more spatially clustered firms experience a decreased LHB effect and location premium. Similar but opposite dynamics are predicted for local delistings, with an increase in the LHB effect and location premium. We argue that the initial 
level of firm clustering plays a significant role in shaping the pricing effects of local IPOs and delistings. Therefore, we expect that the decrease (increase) in the LHB effect caused by an increase (decrease) in the number of local listed firms, due to IPOs (delistings), becomes progressively smaller (higher) the more the issuing firm was originally clustered (isolated). In essence, we predict that the effect of a local IPO in areas with only a few local firms (e.g., one local firm) is higher than the effect of a local IPO in areas with several local firms (e.g., 100 local firms) because, in the first scenario, the portfolio of local firms to invest in effectively doubles and, in the second scenario, the increase in local equity is only equal to $1 \%$.

Operationally, our first step is to perform the cluster analysis of I_FIRM. The dynamic analysis we propose requires testing the relation between the variations of market-to-book and the variations of I_FIRM. Because I_FIRM varies any time there is an IPO or a delisting regardless of whether it is local, I_FIRM variations cannot necessarily capture the changes in firm spatial status from a local perspective. On the other hand, effective variations in the LHB effect can be predicted for all listed firms that are less (more) traded following an IPO (delisting) when local investors re-weight their portfolios based on the new set of available local stocks. Therefore, effective I_FIRM variations only hold for local firms or, formally, for firms belonging to the same spatial cluster. The cluster analysis addresses this issue by endogenously grouping local firms. Ultimately, the cluster analysis provides us with a clustered version of I_FIRM, designated I_FIRM ${ }^{\mathrm{CL}}$, which is given values from one to four (the cluster value) as the number of firms within the cluster increases. In fact, $I$ _FIRM ${ }^{\mathrm{CL}}$ defines the firm spatial status with respect to the other local firms only. Appendix B reports the steps of cluster analysis.

We address the variations in the location premium due to local IPOs and delistings by investigating the relations between the market-to-book and variations of I_FIRM ${ }^{\mathrm{CL}}$. We split I_FIRM ${ }^{\mathrm{CL}}$ into the previous year's value $\left(I_{-} F_{R} M_{t-1}^{\mathrm{CL}}\right)$ plus the year variation $\left(I_{-}\right.$FIRM $\left._{\Delta t}^{\mathrm{CL}}\right)$. While $I_{-}$FIRM $_{t-1}^{\mathrm{CL}}$ refers to the portion of location premium that can be attributed to the initial level of clustering, $I_{-}$FIRM $_{\Delta t}^{\mathrm{CL}}$ refers to the location premium decrease (increase) due to a positive (negative) variation in firm local clustering caused by local IPOs (delistings). We also add the cross-product term of the former with the latter $\left(I_{-} \mathrm{FIRM}_{t-1}^{\mathrm{CL}} \times I_{-} \mathrm{FIRM}_{\Delta t}^{\mathrm{CL}}\right)$. This correction term takes into account the initial level of firm clustering. While $I_{-} F_{R} \mathrm{M}_{t-1}^{\mathrm{CL}}$ is always expected to be inversely related to marketto-book, I_FIRM $\mathrm{CL}_{\Delta t}^{\mathrm{CL}}$ and $I_{-} \mathrm{FIRM}_{t-1}^{\mathrm{CL}} \times I_{-}$FIRM $_{\Delta t}^{\mathrm{CL}}$ are predicted to be negatively and positively related to market-to-book, respectively, due to local IPOs. The opposite is expected for local delistings.

Finally, to further strengthen our analysis, we address the relation between the underpricing and the firm location. More specifically, we investigate the relation between the IPO first-day return and I_FIRM and I_INCOME. I_FIRM is predicted to be inversely related to the IPO first-day return meaning that isolated IPOs are more underpriced than clustered IPOs; I_INCOME is predicted to be directly related to the IPO underpricing.

\section{Data, variable definition, and methodology}

\subsection{Data sources and sample selection}

We investigated several different data sources: (i) the databases provided by Consob (i.e., the Italian regulator) for our sample; (ii) Osiris (Bureau Van Dijk database) and Company Annual Reports for data on firm location; (iii) the archives provided by Borsa Italiana S.p.A. (the MSE's managing company) for information on securities listings and IPO data; (iv) Amadeus (Bureau Van Dijk database) for data on Italian private firms; (v) the electronic archive of Il Sole 240re, the most prominent Italian financial newspaper, for press coverage; (vi) the investment guide Il Calepino dell'Azionista for firm age; (vii) the databases of ISTAT (Italian Institute of Statistics) and Centro Studi Unioncamere (the research center of the regional Chambers of Commerce) for information on wealth distribution; and (viii) Datastream and Worldscope (Thompson Financial) for all other accounting and financial information. In addition, NUTS Codes have been used to split Italy (NUTSO) into three nested subareas, namely, the geographic macroareas (NUTS1), Italian regions (NUTS2), and Italian provinces (NUTS3). Finally, Google Maps allowed us to collect the geographic coordinates (i.e., latitude and longitude) of each sampled firm headquarters. Table A.1 in Appendix A summarizes the information sources.

Our initial sample consists of 2537 firm-year observations for firms issuing common stock on the MSE over the period 19992007. From the initial sample, we extracted observations (i) of actively traded stocks, (ii) with ROE within a range of plus one and minus one, and (iii) headquartered in Italy. The resulting unbalanced panel data set consists of 2463 firm-year observations (151 IPOs) and is our final sample.

\subsection{Methodology and definition of variables}

The logarithmic transformation of the market-to-book ratio (LN(MARKET-TO-BOOK)) is our left-hand side variable. As the main explanatory variable, we start with RATIO (HKS). Consistent with Guiso et al. (2004) and Hasan et al. (2009), we take RATIO at the region level. Then, we replace RATIO with I_FIRM and I_INCOME. Therefore, the static specification of the firm location premium we test is:

$$
\begin{aligned}
\text { LN }(\text { MARKET-TO-BOOK })_{i, t}= & \gamma_{0}+\gamma_{1} * I_{-} \text {FIRM }_{i, t}+\gamma_{3} * I_{-} \text {INCOME }_{i, t} \\
& +\gamma * \text { Controls }_{i, t}+\varepsilon_{i, t}
\end{aligned}
$$

Within this analysis, we distinguish the firms included in the FTSE MIB (FTSE-FIRMS) from those excluded (NON-FTSE-FIRMS) through the interacting dummy variable FTSE_D. Consistent with previous findings (e.g., Gygax and Otchere, 2010; Brisker et al., 2013), the marginal effect of FTSE_D on MARKET-TO-BOOK is expected to be positive. Next, we replace I_FIRM with I_FIRM ${ }^{\mathrm{CL}}$ and test the statistical significance of the relations of LN(MARKET-TO-BOOK) with the first lag and the first difference of $I_{-}$FIRM $^{\mathrm{CL}}$ (i.e., I_FIRM $\mathrm{M}_{t-1}^{\mathrm{CL}}$ and $I_{-}$FIRM $_{\Delta t}^{\mathrm{CL}}$ ) and the cross-product of the former with the latter (i.e., $I_{-}$FIRM $\left._{t-1}^{\mathrm{CL}} \times I_{-} \mathrm{FIRM}_{\Delta t}^{\mathrm{CL}}\right)$. The specification for the location premium dynamic we test is:

$$
\begin{aligned}
\mathrm{LN}(\mathrm{MARKET}-\mathrm{TO}-\mathrm{BOOK})_{i, t}= & \zeta_{0}+\zeta_{1} * I_{\_} \text {FIRM }_{i, t-1}^{\mathrm{CL}}+\zeta_{2} * I_{\_} \mathrm{FIRM}_{i, \Delta t}^{\mathrm{CL}} \\
& +\zeta_{3} * I_{-} \text {FIRM }_{i, t-1}^{\mathrm{CL}} \times I_{-} \mathrm{FIRM}_{i, \Delta t}^{\mathrm{CL}} \\
& +\zeta_{10} * I_{-} \mathrm{INCOME}_{i, t}+\zeta * \text { Controls }_{i, t}+\varepsilon_{i, t}
\end{aligned}
$$

We distinguish the aggregation effect caused by IPOs from the isolation effect caused by delistings. To this end, we introduce two interacting dummy variables, UP_D and DOWN_D, to detect firms that become more or less spatially clustered with other listed firms from one year to another (e.g., UP_D $=1$ if $I_{-}$FIRM $\left._{\Delta t}^{\mathrm{CL}}>0\right)$. When we run our regressions, we exclude observations for financial firms (SIC 6000-6999). However, these observations are retained for computing RATIO and I_FIRM.

In the multivariate analysis, we control for (i) equity profitability (ROE) (e.g., Bagella et al., 2000), (ii) firm future growth opportunities (CAPEX-TO-ASSET) (e.g., Chua et al., 2007), (iii) firm size, defined by total assets (LN(FIRM SIZE)) (e.g., Van Dijk, 2011), (iv) firm age, defined by the number of years of a firm's life since foundation (LN(1 + FIRM AGE)) (e.g., Keloharju and Kulp, 1996), (v) firm press coverage, defined by the yearly number of newspaper articles 
Table 1

Summary statistics.

\begin{tabular}{|c|c|c|c|c|}
\hline & Mean & Median & 25th Percentile & 75th Percentile \\
\hline \multicolumn{5}{|l|}{ Panel A - all Sample } \\
\hline MARKET-TO-BOOK & 2.38 & 1.70 & 1.13 & 2.67 \\
\hline RATIO & 0.482 & 0.515 & 0.179 & 0.645 \\
\hline I_FIRM & 2.846 & 2.880 & 1.559 & 3.812 \\
\hline I_FIRM ${ }^{\mathrm{CL}}$ & 2.672 & 3 & 1 & 4 \\
\hline I_INCOME & 2.051 & 2.177 & 1.881 & 2.271 \\
\hline FTSE_D & 0.10 & 0 & 0 & 0 \\
\hline DEBT-TO-ASSET & $24.75 \%$ & $25.00 \%$ & $11.83 \%$ & $36.27 \%$ \\
\hline PRESS COVERAGE & 29 & 13 & 8 & 23 \\
\hline FIRM AGE (Years) & 40 & 25 & 13 & 58 \\
\hline CAPEX-TO-ASSET & $4.99 \%$ & $3.47 \%$ & $1.62 \%$ & $6.10 \%$ \\
\hline R\&D-TO-SALES & $0.69 \%$ & $0.00 \%$ & $0.00 \%$ & $0.00 \%$ \\
\hline R\&D_D & 0.79 & 1 & 1 & 1 \\
\hline ROE & $3.28 \%$ & $6.27 \%$ & $-0.36 \%$ & $13.04 \%$ \\
\hline FIRM SIZE (Mln €) & 3114 & 363 & 134 & 1400 \\
\hline LOCAL GDP( $€$ per capita $)$ & 15,204 & 15,562 & 14,068 & 16,935 \\
\hline \multicolumn{5}{|l|}{ Panel B - IPO sample } \\
\hline UNDERPRICING & 0.122 & 0.040 & 0.013 & 0.142 \\
\hline I_FIRM & 2.501 & 2.369 & 1.494 & 3.372 \\
\hline I_INCOME & 1.943 & 2.032 & 1.791 & 2.131 \\
\hline$\sigma \mathrm{IPO}_{(30}$ after $)$ & $4.03 \%$ & $2.45 \%$ & $1.54 \%$ & $4.11 \%$ \\
\hline$\sigma \mathrm{m}_{(60 \text { before })}$ & $0.92 \%$ & $0.84 \%$ & $0.67 \%$ & $1.01 \%$ \\
\hline REVISION & 1.291 & 0.313 & 0.000 & 0.667 \\
\hline RANGE & 0.237 & 0.240 & 0.167 & 0.308 \\
\hline REPUTATION & 0.103 & 0.031 & 0.002 & 0.054 \\
\hline INSTITUTIONAL & 0.645 & 0.649 & 0.522 & 0.729 \\
\hline PARTICIPATION RATIO & 0.133 & 0.081 & 0.000 & 0.235 \\
\hline DILUTION FACTOR & 3.195 & 0.250 & 0.111 & 0.389 \\
\hline PROCEEDS (Mln €) & 85.908 & 88.438 & 35.047 & 208.367 \\
\hline FIRM AGE (Years) & 17 & 12 & 4 & 20 \\
\hline FIRM SIZE $($ Mln $€)$ & 1519 & 180 & 68 & 436 \\
\hline INDUSTRY MARKET-TO-BOOK & 0.70 & 0.70 & 0.50 & 0.90 \\
\hline $\mathrm{ROA}$ & $4.44 \%$ & $6.09 \%$ & $2.12 \%$ & $10.49 \%$ \\
\hline DEBT-TO-ASSET & $30.71 \%$ & $27.42 \%$ & $8.60 \%$ & $46.64 \%$ \\
\hline \multicolumn{5}{|l|}{ Panel $C$ - private firms sample } \\
\hline I_FIRM & 2.866 & 2.455 & 1.542 & 3.449 \\
\hline I_INCOME & 1.932 & 2.009 & 1.755 & 2.106 \\
\hline INDUSTRY MARKET-TO-BOOK & 0.72 & 0.67 & 0.48 & 0.95 \\
\hline ROA & $8.45 \%$ & $7.22 \%$ & $3.99 \%$ & $11.91 \%$ \\
\hline DEBT-TO-ASSET & $15.45 \%$ & $11.72 \%$ & $5.51 \%$ & $21.35 \%$ \\
\hline
\end{tabular}

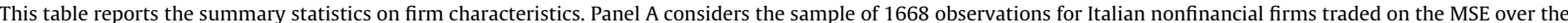

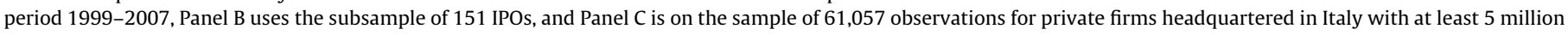

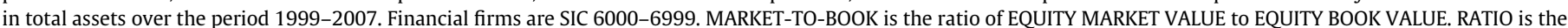

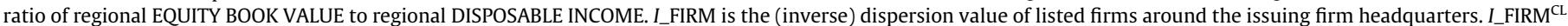

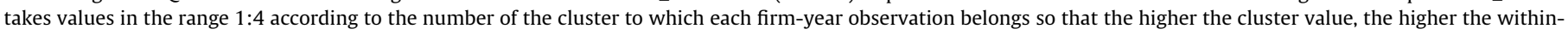

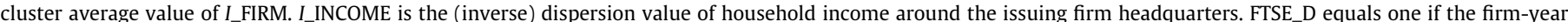

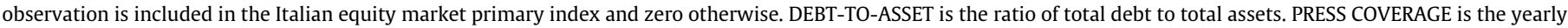

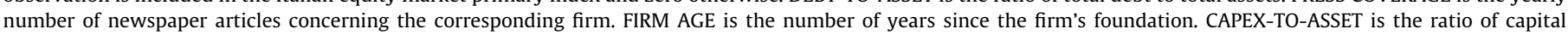

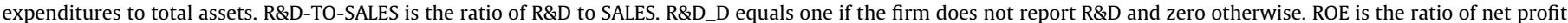

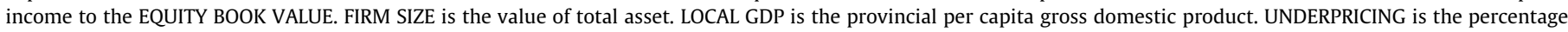

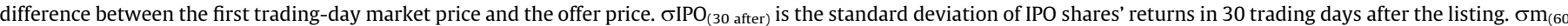

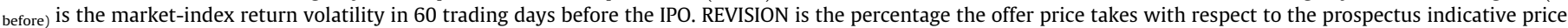

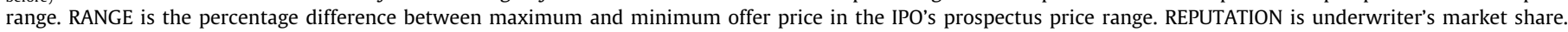

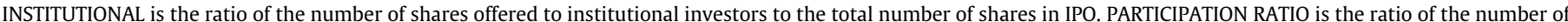

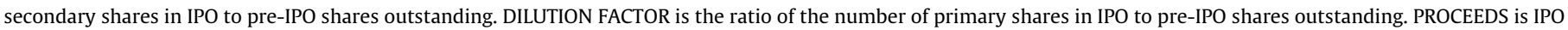
proceeds. INDUSTRY MARKET-TO-BOOK is the median market-to-book ratio of listed firms in the same industry. ROA is the ratio of EBITDA to total assets.

published on the firm under consideration (LN(1 + PRESS COVERAGE)) (e.g., Birz and Lott, 2011), and (vi) firm leverage (DEBT-TOASSET) (e.g., Arena and Dewally, 2012). In addition, we include in all regressions (not shown) (vii) a set of four-digit SIC industry dummies (Chou et al., 2012), (viii) a set of exchange segment listing dummies (Tse and Devos, 2004), and (ix) a set of year dummies. Finally, to control for further unobservable regional effects when our regression models include RATIO, we cluster standard errors at the region level. Otherwise, we control for any possible crosssectional and time-series correlation by clustering standard errors both at the firm and year level, consistent with Petersen (2009).

When we address the relation between underpricing and firm location, the percentage difference between the first trading-day market price and the offer price (UNDERPRICING) is the left-hand side variable and I_FIRM and I_INCOME are the main explanatory variables. We control for (i) the IPO shares volatility $\left(\sigma \mathrm{IPO}_{(30 \text { after })}\right)$ (e.g., Lowry et al., 2010), (ii) the market volatility before the IPO $\left(\sigma \mathrm{m}_{(60 \text { before }}\right)($ e.g., Cassia et al., 2004), (iii and iv) the IPO price revision (REVISION) (e.g., Ljungqvist and Wilhelm, 2003) and range (RANGE) (e.g., Hanley, 1993), (v) underwriters reputation (REPUTATION) (e.g., Megginson and Weiss, 1991), (vi) subscribers (INSTITUTIONAL) (e.g., Aggarwal et al., 2002), (vii-ix) the offer composition (PARTICIPATION RATIO and DILUITION FACTOR) (e.g., Ljungqvist and Wilhelm, 2003), and size (LN(1 + PROCEEDS)) (e.g., Cassia et al., 2004), and ( $\mathrm{x}$ and xi) the firm age (LN(1 + FIRM AGE)) and size (LN(FIRM SIZE)) (e.g., Loughran and Ritter, 2004). 
Table 2

RATIO and I_FIRM and I_INCOME: the local supply and demand for stocks. Descriptive statistics.

\begin{tabular}{|c|c|c|c|c|c|c|}
\hline \multicolumn{2}{|c|}{ ITALY - MACROAREA - REGION } & $\begin{array}{l}\text { LISTED FIRMS } \\
\text { (Firm-Year Obs.) } \\
(2)\end{array}$ & $\begin{array}{l}\text { NONFINANCIAL LISTED FIRMS } \\
\text { (Firm-Year Obs.) } \\
(3)\end{array}$ & $\begin{array}{l}\text { RATIO } \\
(4) \\
\end{array}$ & $\begin{array}{l}\text { I_FIRM } \\
(5)\end{array}$ & $\begin{array}{l}\text { I_INCOME } \\
(6)\end{array}$ \\
\hline $\begin{array}{l}\text { NUTSO - COUNTRY } \\
\text { Italy }\end{array}$ & & 2463 & 1668 & 0.325 & 2.933 & 1.851 \\
\hline $\begin{array}{l}\text { NUTS1 - MACROAREA } \\
\text { Center } \\
\text { Islands } \\
\text { Northeast } \\
\text { Northwest } \\
\text { South }\end{array}$ & $\begin{array}{l}(\mathrm{C}) \\
(\mathrm{I}) \\
(\mathrm{NE}) \\
(\mathrm{NW}) \\
(\mathrm{S})\end{array}$ & $\begin{array}{r}494 \\
20 \\
510 \\
1400 \\
39\end{array}$ & $\begin{array}{r}349 \\
17 \\
401 \\
871 \\
30\end{array}$ & $\begin{array}{l}0.497 \\
0.013 \\
0.158 \\
0.595 \\
0.003\end{array}$ & $\begin{array}{l}1.390 \\
1.108 \\
2.324 \\
3.782 \\
1.242\end{array}$ & $\begin{array}{l}1.616 \\
1.522 \\
2.199 \\
2.019 \\
1.662\end{array}$ \\
\hline \multicolumn{6}{|l|}{ NUTS2 - REGION } & 1.534 \\
\hline Aosta Valley & NW & 0 & 0 & 0.000 & 0.000 & 1.816 \\
\hline Apulia & S & 5 & 2 & 0.002 & 1.209 & 1.568 \\
\hline Basilicata & $\mathrm{S}$ & 0 & 0 & 0.000 & 0.000 & 1.630 \\
\hline Calabria & $\mathrm{S}$ & 0 & 0 & 0.000 & 0.000 & 1.583 \\
\hline Campania & $\mathrm{S}$ & 22 & 16 & 0.005 & 1.228 & 1.662 \\
\hline Emilia-Romagna & $\mathrm{NE}$ & 281 & 228 & 0.144 & 2.458 & 2.271 \\
\hline Friuli-Venezia Giulia & NE & 54 & 42 & 0.496 & 1.463 & 1.779 \\
\hline Lazio & C & 300 & 227 & 0.920 & 1.305 & 1.505 \\
\hline Liguria & NW & 63 & 34 & 0.608 & 3.014 & 2.047 \\
\hline Lombardy & NW & 1033 & 627 & 0.559 & 4.068 & 2.248 \\
\hline Marche & $\mathrm{C}$ & 44 & 32 & 0.045 & 1.383 & 1.616 \\
\hline Molise & S & 10 & 10 & 0.037 & 1.263 & 1.624 \\
\hline Piedmont & NW & 304 & 210 & 0.691 & 2.976 & 2.019 \\
\hline Sardinia & I & 11 & 11 & 0.044 & 1.093 & 1.226 \\
\hline Sicily & I & 9 & 6 & 0.002 & 1.135 & 1.522 \\
\hline Trentino Alto Adige & $\mathrm{NE}$ & 3 & 3 & 0.002 & 3.231 & 2.104 \\
\hline Tuscany & $\mathrm{C}$ & 141 & 90 & 0.178 & 1.575 & 2.017 \\
\hline Umbria & $\mathrm{C}$ & 9 & 0 & 0.009 & 1.356 & 1.556 \\
\hline Veneto & $\mathrm{NE}$ & 172 & 128 & 0.117 & 2.370 & 2.199 \\
\hline
\end{tabular}

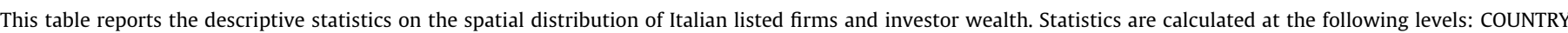

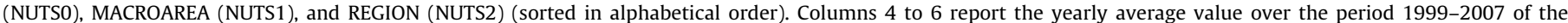

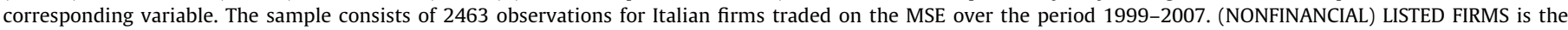

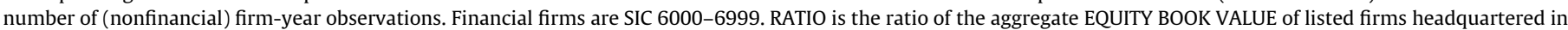

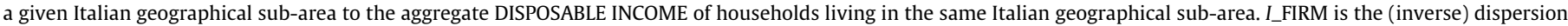

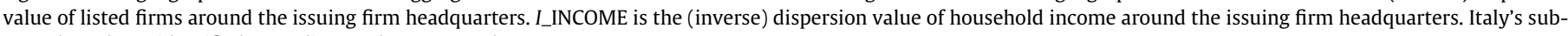
areas have been identified according to the NUTS Codes.

We also control for potential self-selection bias (Heckman, 1979) which may affect firms going public (e.g., Chemmanur et al., 2010). To this end, we use the sample of Italian private firms with at least 5 million in total assets (61,057 firm-year observations) and test a probit model for the decision to go public (e.g., Pagano et al., 1998): Each year the dependent variable equals zero if the firm stays private and one if it goes public (IPO_D). In addition to I_FIRM and I_INCOME, we control for (i and ii) firm age (LN(1 + FIRM AGE)) and size (LN(FIRM SIZE)) (e.g., Chemmanur et al., 2010), (iii) IPO timing (INDUSTRY MARKET-TO-BOOK) (e.g., Pagano et al., 1998), and (iv and v) firm profitability (ROA) and leverage (DEBT-TO-ASSET) (e.g., Pagano et al., 1998). Afterwards, we augment the UNDERPRICING regression model with the Heckman's $\lambda$, (i.e., the inverse Mills ratio). In econometric models, standard errors are clustered both by year and sub-sector.

Table 1 reports descriptive statistics for listed firms (Panel A), IPOs (Panel B), and private firms (Panel C).

Panel A indicates I_FIRM has a higher variability than I_INCOME. In fact, in terms of the 25 th and 75 th percentiles, the I_FIRM values are within the 1.559-3.812 range, while I_INCOME is within the 1.8812.271 range. This evidence highlights a mismatch between the spatial distribution of listed firms and per capita disposable income: Statistics indicate the copresence of areas densely populated by listed firms (e.g., when I_FIRM is equal to 3.812 ) with areas nearly devoid of them (e.g., when I_FIRM is equal to 1.559), together with the simultaneous widespread distribution of investor wealth (I_INCOME is always approximately 2). Existing local imbalances between the local demand and local supply for stocks is the necessary precondition to profitably employ the HKS framework; in addition, local imbalances ex ante minimize the alleged correlation between I_FIRM and I_INCOME. Statistics on the other variables are consistent with prior studies (e.g., Aabo et al., 2013) and suggest the investigated sample is representative. Finally, Panel B and Panel C highlight that I_FIRM and I_INCOME are essentially unchanged both for IPOs and private firms, indicating that the spatial distribution for Italian IPOs, listed and private firms are similar. Therefore, any possible bias due to unobservable local features affecting the results should be minimal.

Table A.2 in Appendix A provides detailed definitions of the variables here employed.

\section{The anatomy of I_FIRM and I_INCOME}

Table 2 describes the spatial distribution of the local supply and demand for stocks. Fig. 2 depicts the data: The left-side picture plots the locations of sampled firms, and the right-side picture displays the spatial patterns of RATIO, as well as I_FIRM and I_INCOME.

With regard to frequencies (cf. column 2 and 3 of Table 2), Italian listed firms tend to geographically cluster in only a few areas, particularly in northern Italy where $77.5 \%$ of the whole sample are headquartered. The Northwest accounts for $56.8 \%$ of sampled firms, so it is not surprising that the region of Lombardy contains the most listed firms, accounting for 1033 firm-year observations or $41.9 \%$ of the whole data set. The central and southern areas of 


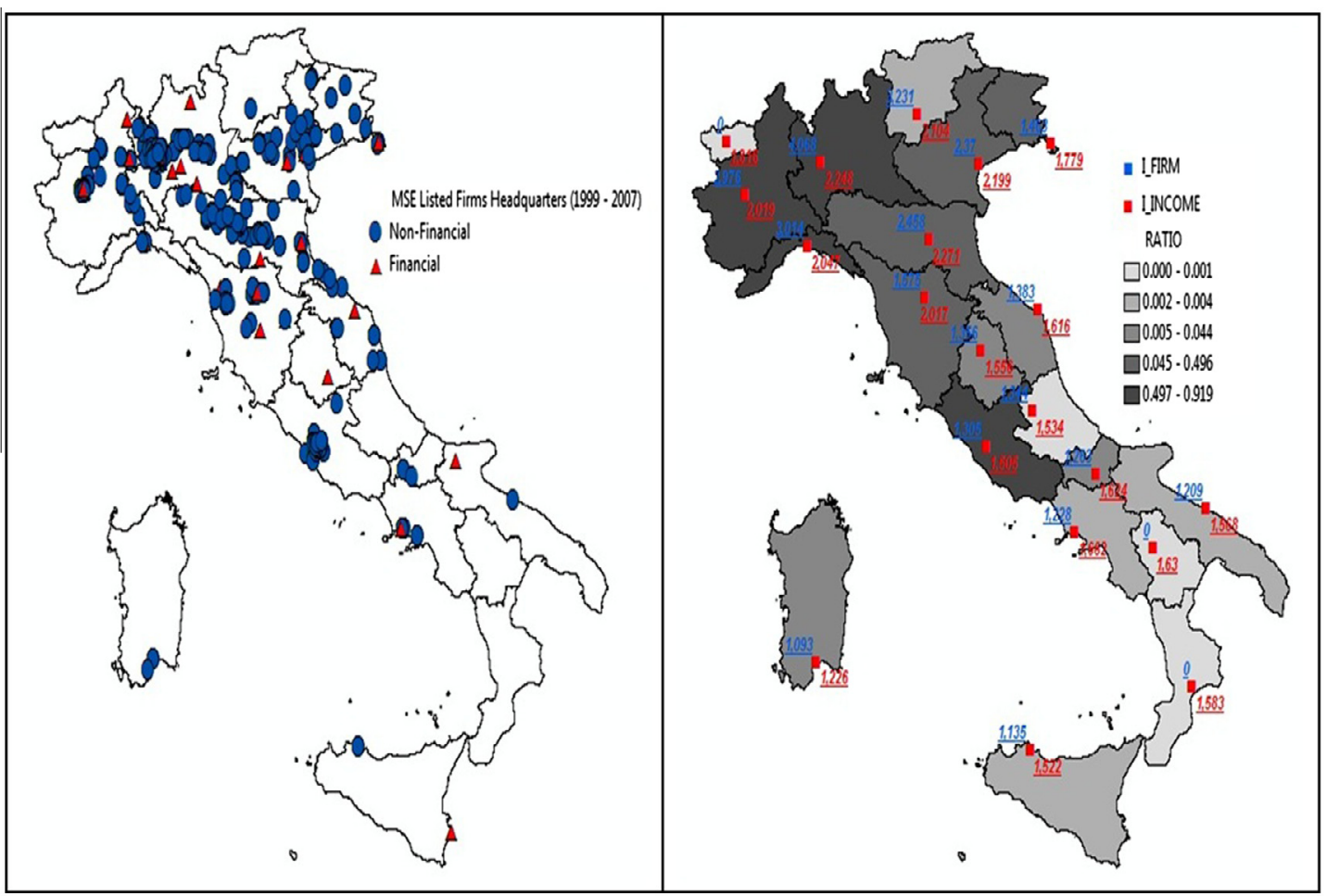

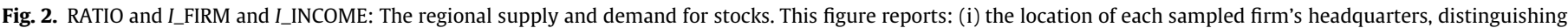

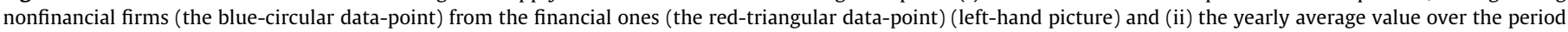

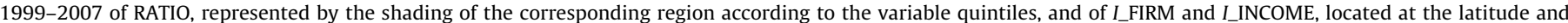

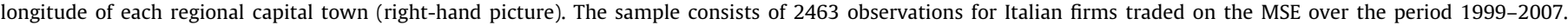

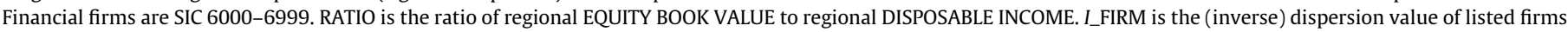

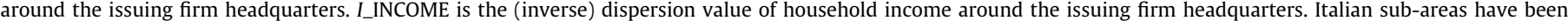

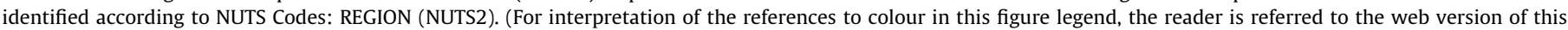
article.)

Italy including the islands account for a total of 553 firm-year observations or $22.5 \%$ of the whole data set. This area includes Lazio (Central Italy including the city of Rome), which alone accounts for $12.2 \%$ of the whole data set. ${ }^{2}$ Therefore, it follows logically that the northern regions are generally characterized by RATIO values above the national mean, and the central and southern areas (including the islands) exhibit lower than average values (cf. column 4 of Table 2). In fact, the Northwest is first, averaging 0.595, and the Center follows with 0.497 . On the other hand, in terms of the regional distribution, the highest value of RATIO is registered in Lazio, averaging 0.920. Piedmont is second, with an average RATIO of 0.691. At the other extreme, Abruzzo (South) averages 0.001, and Apulia (South), Sicily (Islands), and Trentino Alto Adige (Northeast) average 0.002 .

The same tendencies, though more pronounced, emerge using I_FIRM and I_INCOME (cf. column 5 and 6 of Table 2). In fact, although spatial patterns are substantially unchanged when summarized by RATIO or by I_FIRM and I_INCOME, the values of I_FIRM and I_INCOME appear more consistent with the actual spatial distribution of listed firms and investor wealth. For instance, because of the firm clustering in Lombardy, the geographically close regions of Trentino Alto Adige (average value of I_FIRM equal to 3.231) and Liguria (3.014) are now second and third, respectively. Similarly, while Lazio ranks first by RATIO, it is in twelfth place by I_FIRM

\footnotetext{
2 This evidence is caused by the clustering of state-owned enterprises (SOEs) around the Italian capital. Consistent with previous evidence (e.g., Faccio and Lang 2002), SOEs account for $8.1 \%$ of our sample, with an impressive $32.4 \%$ headquartered in Rome.
}

(1.305), which is consistent with the figures indicating that, apart from the clustering in Rome, neighboring areas are almost devoid of listed firms. Overall, the descriptive statistics confirm that I_FIRM and I_INCOME are more refined measures of the local equity market conditions with respect to RATIO.

\section{The firm location premium}

In this section, we test the significance of the relations between LN(MARKET-TO-BOOK) and RATIO as well as I_FIRM and I_INCOME. We distinguish FTSE-FIRMS from NON-FTSE-FIRMS. We expect a negative relation between RATIO and MARKETTO-BOOK (i.e., $\beta_{1}<0$ ). Similarly, while I_FIRM is predicted to negatively affect MARKET-TO-BOOK, I_INCOME is expected to have a positive effect (i.e., $\gamma_{1}<0$ and $\gamma_{3}>0$ ). Finally, we expect that the MARKET-TO-BOOK of FTSE-FIRMS is less affected by RATIO, I_FIRM and I_INCOME than the MARKET-TO-BOOK of NON-FTSE-FIRMS (e.g., $\gamma_{1}+\gamma_{2}>\gamma_{1}$ ). Table 3 reports the results for models $1-3$, which include RATIO, while models 4-6 use I_FIRM and $I_{-}$INCOME.

As expected, the effect of RATIO on LN(MARKET-TO-BOOK) is negative and significant (Model $1: \beta_{1}=-0.175, p$-value $<0.10$ ). Once controls are introduced, the effect of RATIO is still negative and significant (Model 2: $\beta_{1}=-0.085, p$-value $<0.10$ ). In addition, while the relation between RATIO and LN(MARKET-TO-BOOK) remains negative and statistically significant for NON-FTSE-FIRMS (Model 3: $\beta_{1}=-0.125, p$-value $<0.05$ ), it is no longer significant for FTSE-FIRMS as predicted (Model 3: $\beta_{1}+\beta_{2}=0.160, p$-value $>0.10$ ). Finally, all control variables have the predicted pattern. 
Table 3

The effect of RATIO and I_FIRM and I_INCOME on MARKET-TO-BOOK.

\begin{tabular}{|c|c|c|c|c|c|c|c|}
\hline \multirow[t]{3}{*}{ Independent variables } & & \multicolumn{6}{|c|}{ Dependent variable: LN(MARKET-TO-BOOK) } \\
\hline & & \multicolumn{3}{|c|}{ RATIO } & \multicolumn{3}{|c|}{ I_FIRM \& I_INCOME } \\
\hline & & (1) & $(2)$ & (3) & $(4)$ & $(5)$ & (6) \\
\hline Constant & & $\begin{array}{l}0.518^{* * * *} \\
(3.67)\end{array}$ & $\begin{array}{l}1.057^{* * * *} \\
(5.01)\end{array}$ & $\begin{array}{l}1.394^{* * * *} \\
(5.24)\end{array}$ & $\begin{array}{l}0.048 \\
(0.20)\end{array}$ & $\begin{array}{l}0.553^{* *} \\
(2.28)\end{array}$ & $\begin{array}{l}0.845^{* *} \\
(2.89)\end{array}$ \\
\hline RATIO & $\beta_{1}$ & $\begin{array}{l}-0.175^{*} \\
(-1.93)\end{array}$ & $\begin{array}{l}-0.085^{*} \\
(-1.82)\end{array}$ & $\begin{array}{l}-0.125^{* *} \\
(-2.59)\end{array}$ & & & \\
\hline RATIO*FTSE_D & $\beta_{2}$ & & & $\begin{array}{l}0.285^{* * * *} \\
(3.70)\end{array}$ & & & \\
\hline I_FIRM & $\gamma_{1}$ & & & & $\begin{array}{l}-0.078^{* * *} \\
(-3.03)\end{array}$ & $\begin{array}{l}-0.063^{* *} \\
(-2.78)\end{array}$ & $\begin{array}{l}-0.068^{* * *} \\
(-2.98)\end{array}$ \\
\hline I_FIRM*FTSE_D & $\gamma_{2}$ & & & & & & $\begin{array}{l}0.046 \\
(0.21)\end{array}$ \\
\hline I_INCOME & $\gamma_{3}$ & & & & $\begin{array}{l}0.290^{* * *} \\
(3.45)\end{array}$ & $\begin{array}{l}0.263^{* * *} \\
(4.33)\end{array}$ & $\begin{array}{l}0.292^{* * *} \\
(4.51)\end{array}$ \\
\hline I_INCOME*FTSE_D & $\gamma_{4}$ & & & & & & $\begin{array}{l}-0.282 \\
(-0.37)\end{array}$ \\
\hline FTSE_D & $\beta_{\mathrm{FTSE}}, \gamma_{\mathrm{FTSE}}$ & & & $\begin{array}{l}0.159 \\
(1.35)\end{array}$ & & & $\begin{array}{l}0.756 \\
(0.81)\end{array}$ \\
\hline DEBT-TO-ASSET & & & $\begin{array}{l}0.202 \\
(0.98)\end{array}$ & $\begin{array}{l}0.250 \\
(1.21)\end{array}$ & & $\begin{array}{l}0.179 \\
(0.87)\end{array}$ & $\begin{array}{l}0.237 \\
(1.12)\end{array}$ \\
\hline LN(1 + PRESS COVERAGE) & & & $\begin{array}{l}0.277^{* * * *} \\
(6.56)\end{array}$ & $\begin{array}{l}0.246^{* * * *} \\
(6.34)\end{array}$ & & $\begin{array}{l}0.277^{* * *} \\
(6.64)\end{array}$ & $\begin{array}{l}0.246^{* * * *} \\
(6.42)\end{array}$ \\
\hline LN(1 + FIRM AGE) & & & $\begin{array}{l}-0.120 \\
(-2.06)\end{array}$ & $\begin{array}{l}-0.132^{* *} \\
(-2.53)\end{array}$ & & $\begin{array}{l}-0.118^{*} \\
(-2.00)\end{array}$ & $\begin{array}{l}-0.131^{* *} \\
(-2.65)\end{array}$ \\
\hline CAPEX-TO-ASSET & & & $\begin{array}{l}-0.069 \\
(-0.29)\end{array}$ & $\begin{array}{l}-0.062 \\
(-0.26)\end{array}$ & & $\begin{array}{l}-0.047 \\
(-0.19)\end{array}$ & $\begin{array}{l}-0.027 \\
(-0.11)\end{array}$ \\
\hline ROE & & & $\begin{array}{l}0.416^{* * * *} \\
(3.18)\end{array}$ & $\begin{array}{l}0.407^{* * *} \\
(3.03)\end{array}$ & & $\begin{array}{l}0.402^{* * * *} \\
(3.06)\end{array}$ & $\begin{array}{l}0.396^{* * *} \\
(2.90)\end{array}$ \\
\hline LN(FIRM SIZE) & & & $\begin{array}{l}-0.067^{\text {*** }} \\
(-2.40)\end{array}$ & $\begin{array}{l}-0.087^{* * * *} \\
(-2.96)\end{array}$ & & $\begin{array}{l}-0.060^{* * *} \\
(-2.21)\end{array}$ & $\begin{array}{l}-0.081^{* *} \\
(-2.85)\end{array}$ \\
\hline Observations & & 1460 & 1410 & 1410 & 1460 & 1410 & 1410 \\
\hline Adjusted $R$-squared & & 0.36 & 0.47 & 0.48 & 0.36 & 0.47 & 0.48 \\
\hline
\end{tabular}

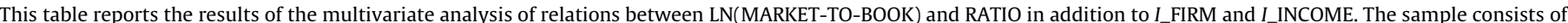

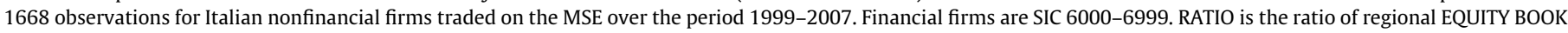

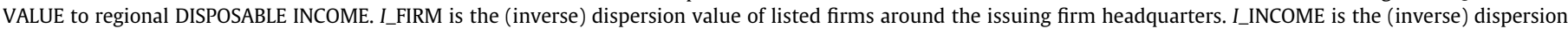

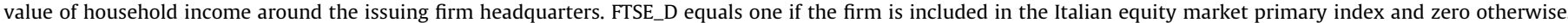

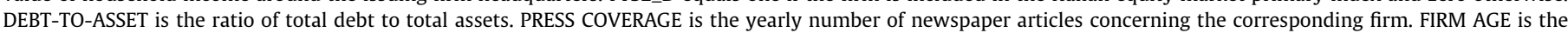

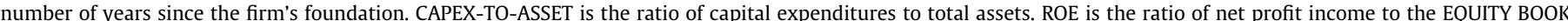

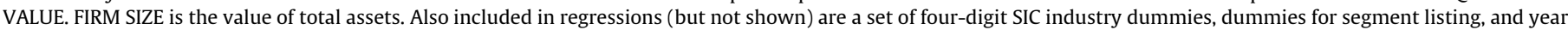

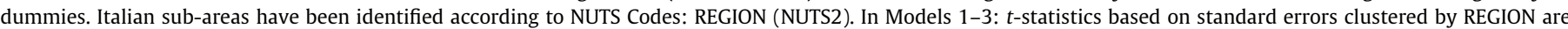
reported in parentheses. In Models 4-6: $t$-statistics based on standard errors clustered by firm and year are reported in parentheses.

Statistical significance at the $10 \%$ level.

** Statistical significance at the 5\% level.

*** Statistical significance at the $1 \%$ level.

Economically, a measure of the firm location premium can be inferred by considering the average sampled NON-FTSE-FIRMS for which the MARKET-TO-BOOK is 2.24 and RATIO equals 0.463 . Our results imply that, ceteris paribus, $42.13 \%$ of MARKET-TO-BOOK is attributable to RATIO: When RATIO goes from the 25th to 75th percentile (i.e., from 0.160 to 0.645 ), the percentage change in the MARKET-TO-BOOK equals $-5.88 \%$ due to the decrease in the location premium.

The evidence from I_FIRM and I_INCOME is similar. Indeed, both I_FIRM and I_INCOME are significantly related with LN(MARKET-TO-BOOK). As expected, while the relation of LN(MARKETTO-BOOK) with I_FIRM is negative (Model 4: $\gamma_{1}=-0.078$, $p$-value $<0.01$ ), the relation of LN(MARKET-TO-BOOK) with I_INCOME is positive (Model 4: $\gamma_{3}=0.290, p$-value $<0.01$ ). Once control variables are included, the pattern remains unchanged (Model 5: $\gamma_{1}=-0.063, p$-value $<0.05 ; \gamma_{3}=0.263, p$-value $<0.01$ ). Furthermore, when FTSE-FIRMS and NON-FTSE-FIRMS are investigated, I_FIRM and I_INCOME are still negatively and positively related, respectively, with LN(MARKET-TO-BOOK) (Model 6: $\gamma_{1}=-0.068, p$-value $<0.01 ; \gamma_{3}=0.292, p$-value $\left.<0.01\right)$. At the same time, as predicted, the effects of I_FIRM and I_INCOME on LN(MARKET-TO-BOOK) are not significant when only FTSE-FIRMS are considered (Model 6: $\gamma_{1}+\gamma_{2}=-0.022, \quad p$-value $>0.10$; $\gamma_{3}+\gamma_{4}=0.010, p$-value $\left.>0.10\right)$. Finally, the pattern of the control variables is as expected and unchanged.

Economically, consider once more the average sampled NONFTSE-FIRMS, for which I_FIRM is 2.828 and I_INCOME is 2.067 . Our findings imply that, ceteris paribus, 36.83\% of MARKET-TOBOOK is attributable to I_FIRM. In fact, $-0.192(-0.192=-0.068$ $x$ 2.828) is the estimated LN(MARKET-TO-BOOK) attributable to I_FIRM, and $0.825\left(0.825=e^{(-0.192)}\right)$ is the corresponding estimated MARKET-TO-BOOK, which is $36.83 \%(0.3683=0.825 / 2.24)$ of MARKET-TO-BOOK. On the other hand, I_INCOME is found to have a weight of $81.64 \%$, implying it affects MARKET-TO-BOOK 2.22 times $(2.22=0.8164 / 0.3683)$ stronger than I_FIRM. Overall, $67.35 \%$ of MARKET-TO-BOOK is due to the joint effect of I_FIRM and I_INCOME. From a more dynamic perspective, when I_FIRM goes from the 25th to 75 th percentile (from 1.630 to 3.811 ), the variation in the MARKET-TO-BOOK is equal to $-13.78 \%$. On the other hand, because investor wealth is more homogeneously distributed than listed firms, the same variation for I_INCOME (from 1.899 to 2.283) implies a positive (lower) percentage change in the MARKET-TO-BOOK, which is equal to $11.85 \%$. When both I_FIRM and I_INCOME vary from the 25th to the 75 th percentiles, the 
Table 4

The effect of variations of $I \_F I R M^{\mathrm{CL}}$ on MARKET-TO-BOOK.

\begin{tabular}{|c|c|c|c|c|}
\hline \multirow[t]{2}{*}{ Independent variables } & & \multicolumn{3}{|c|}{ Dependent variable: LN(MARKET-TO-BOOK) } \\
\hline & & $(1)$ & $(2)$ & (3) \\
\hline Constant & & $\begin{array}{l}0.768 \\
(1.73)\end{array}$ & & \\
\hline I_FIRM ${ }^{\mathrm{CL}}$ & $\delta_{4}$ & $\begin{array}{l}-0.055^{* *} \\
(-2.80)\end{array}$ & & \\
\hline$I_{-} \mathrm{FIRM}_{t-1}^{\mathrm{CL}}$ & $\zeta_{1}$ & & $\begin{array}{l}-0.054^{* *} \\
(-2.39)\end{array}$ & $\begin{array}{l}-0.063^{* * *} \\
(-3.01)\end{array}$ \\
\hline$I_{-} \mathrm{FIRM}_{\Delta t}^{\mathrm{CL}}$ & $\zeta_{2}$ & & $\begin{array}{l}-0.037 \\
(-0.92)\end{array}$ & \\
\hline$I_{-} \mathrm{FIRM}_{t-1}^{\mathrm{CL}} \times I_{-} \mathrm{FIRM}_{\Delta t}^{\mathrm{CL}}$ & $\zeta_{3}$ & & $\begin{array}{l}-0.001 \\
(-0.03)\end{array}$ & \\
\hline$I_{-} \mathrm{FIRM}_{t-1}^{\mathrm{CL}} \times U P \_D$ & $\zeta_{4}$ & & & $\begin{array}{l}-1.690^{* * *} \\
(-7.98)\end{array}$ \\
\hline$I_{-} \mathrm{FIRM}_{\Delta t}^{\mathrm{CL}} \times U P_{-} D$ & $\zeta_{5}$ & & & $\begin{array}{l}-1.693^{* * *} \\
(-6.43)\end{array}$ \\
\hline$I_{-} \mathrm{FIRM}_{t-1}^{\mathrm{CL}} \times I_{-} \mathrm{FIRM}_{\Delta t}^{\mathrm{CL}} \times U P D$ & $\zeta_{6}$ & & & $\begin{array}{l}1.618^{* * *} \\
(7.25)\end{array}$ \\
\hline UP_D & $\zeta_{\mathrm{UP}}$ & & & $\begin{array}{l}1.602^{* * *} \\
(6.43)\end{array}$ \\
\hline$I_{-} \mathrm{FIRM}_{t-1}^{\mathrm{CL}} \times D O W N D$ & $\zeta_{7}$ & & & $\begin{array}{l}-0.482^{* *} \\
(-2.93)\end{array}$ \\
\hline$I_{-} \mathrm{FIRM}_{\Delta t}^{\mathrm{CL}} \times D O W N \_D$ & $\zeta_{8}$ & & & $\begin{array}{l}1.618^{* * *} \\
(3.87)\end{array}$ \\
\hline$I_{-} \mathrm{FIRM}_{t-1}^{\mathrm{CL}} \times I_{-} \mathrm{FIRM}_{\Delta t}^{\mathrm{CL}} \times D O W N D$ & $\zeta_{9}$ & & & $\begin{array}{l}-0.430^{* * *} \\
(-3.36)\end{array}$ \\
\hline DOWN_D & $\zeta_{\text {Down }}$ & & & $\begin{array}{l}1.599^{* * * *} \\
(3.40)\end{array}$ \\
\hline I_INCOME & $\delta_{11}, \zeta_{11}$ & $\begin{array}{l}0.257^{* * *} \\
(3.67)\end{array}$ & $\begin{array}{l}0.271^{* * * *} \\
(3.29)\end{array}$ & $\begin{array}{l}0.311^{* * *} \\
(3.53)\end{array}$ \\
\hline DEBT-TO-ASSET & & $\begin{array}{l}0.247 \\
(1.30)\end{array}$ & $\begin{array}{l}0.211 \\
(0.95)\end{array}$ & $\begin{array}{l}0.200 \\
(0.94)\end{array}$ \\
\hline LN(1 + PRESS COVERAGE $)$ & & $\begin{array}{l}0.272^{* * *} \\
(7.07)\end{array}$ & $\begin{array}{l}0.280^{* * *} \\
(7.12)\end{array}$ & $\begin{array}{l}0.280^{* * * *} \\
(7.03)\end{array}$ \\
\hline LN(1 + FIRM AGE) & & $\begin{array}{l}-0.099 \\
(-1.63)\end{array}$ & $\begin{array}{l}-0.111^{*} \\
(-1.81)\end{array}$ & $\begin{array}{l}-0.108 \\
(-1.74)\end{array}$ \\
\hline CAPEX-TO-ASSET & & $\begin{array}{l}-0.102 \\
(-0.30)\end{array}$ & $\begin{array}{l}-0.368 \\
(-0.93)\end{array}$ & $\begin{array}{l}-0.389 \\
(-1.02)\end{array}$ \\
\hline ROE & & $\begin{array}{l}0.346^{* *} \\
(2.19)\end{array}$ & $\begin{array}{l}0.331^{* * *} \\
(2.47)\end{array}$ & $\begin{array}{l}0.361^{* *} \\
(2.53)\end{array}$ \\
\hline LN(FIRM SIZE) & & $\begin{array}{l}-0.088^{* *} \\
(-2.77)\end{array}$ & $\begin{array}{l}-0.090^{* *} \\
(-2.57)\end{array}$ & $\begin{array}{l}-0.086^{* *} \\
(-2.42)\end{array}$ \\
\hline Observations & & 1268 & 1068 & 1068 \\
\hline Adjusted $R$-squared & & 0.44 & 0.43 & 0.43 \\
\hline
\end{tabular}

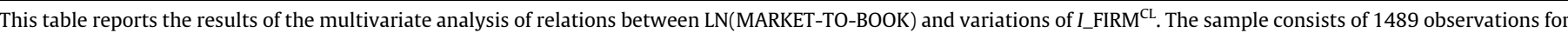

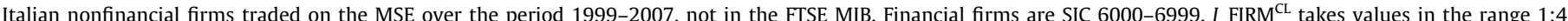

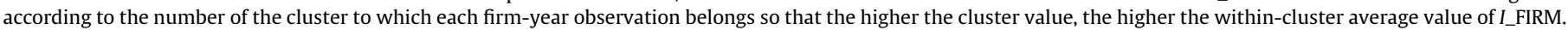

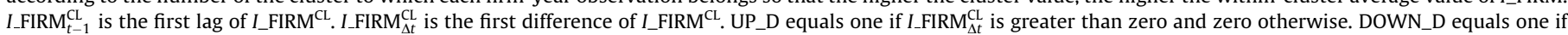

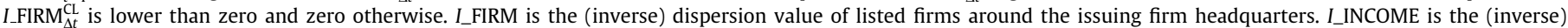

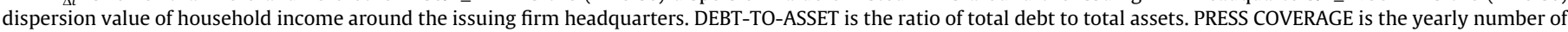

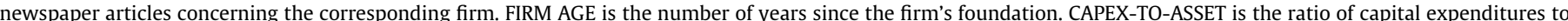

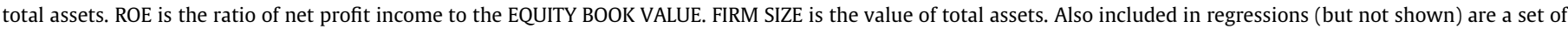

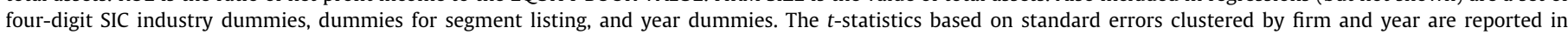
parentheses.

* Statistical significance at the $10 \%$ level.

** Statistical significance at the 5\% level.

*** Statistical significance at the $1 \%$ level.

MARKET-TO-BOOK variation equals $-3.57 \%$ due to an offset of the (decrease in the) LHB effect with the (increase in the) local investor risk tolerance.

\section{Local IPOs, local delistings and the dynamic of the firm location premium}

In this section, we test the significance of the relation between LN(MARKET-TO-BOOK) and the variations of the LHB. The variable I_FIRM ${ }^{\mathrm{CL}}$ defines the firm local clustering and proxies the LHB. We jointly test the significance of the relations of LN(MARKET-TO$\mathrm{BOOK})$ with $I_{-} \mathrm{FIRM}_{t-1}^{\mathrm{CL}}, I_{-} \mathrm{FIRM}_{\Delta t}^{\mathrm{CL}}$, and $I_{-} \mathrm{FIRM}_{t-1}^{\mathrm{CL}} \times I_{-} \mathrm{FIRM}_{\Delta t}^{\mathrm{CL}}$. We distinguish the aggregation effect caused by IPOs (UP_D) from the isolation effect of delistings (DOWN_D). A negative relation is expected between $I_{-}$FIRM $_{t-1}^{\mathrm{CL}}$ and MARKET-TO-BOOK (i.e., $\zeta_{1}<0$ ). On the other hand, while I_FIRM $\mathrm{Cl}_{\Delta t}^{\mathrm{CL}}$ and I_FIRM ${ }_{t-1}^{\mathrm{CL}} \times I_{-} \mathrm{FIRM}_{\Delta t}^{\mathrm{CL}}$ are predicted to be negatively and positively related with MARKET-TOBOOK when the effect of local IPOs is considered (i.e., $\zeta_{5}<0$ and $\zeta_{6}>0$ ), the opposite pattern is predicted for local delistings (i.e., $\zeta_{8}>0$ and $\left.\zeta_{9}<0\right)$. Table 4 reports the results. Model 1 is the base specification: It mimics Model 5 of Table 3 after I_FIRM has been replaced with I_FIRM ${ }^{\mathrm{CL}}$. In Model 2, variations of $I_{-}$FIRM $^{\mathrm{CL}}$ are addressed, while Model 3 distinguishes between the effects of local IPOs and delistings.

The effect of I_FIRM ${ }^{\mathrm{CL}}$ on LN(MARKET-TO-BOOK) is negative and significant as expected (Model 1: $\delta_{4}=-0.055, p$-value $<0.05$ ). Most 
Table 5

The effect of $I$ FIRM and I_INCOME on UNDERPRICING.

\begin{tabular}{|c|c|c|c|c|c|c|}
\hline \multirow[t]{2}{*}{ Independent variables } & & \multicolumn{5}{|c|}{ Dependent variable } \\
\hline & & $\begin{array}{l}\text { UNDERPRICING } \\
\text { (1) }\end{array}$ & $\begin{array}{l}\text { UNDERPRICING } \\
(2)\end{array}$ & $\begin{array}{l}\text { IPO_D } \\
(3)\end{array}$ & $\begin{array}{l}\text { IPO_D } \\
(4)\end{array}$ & $\begin{array}{l}\text { UNDERPRICING } \\
\text { (5) }\end{array}$ \\
\hline Constant & & $\begin{array}{l}-0.290 \\
(-1.09)\end{array}$ & $\begin{array}{l}-0.432^{* *} \\
(-2.38)\end{array}$ & $\begin{array}{l}-4.768^{* * *} \\
(-15.54)\end{array}$ & $\begin{array}{l}-5.936^{* * *} \\
(-8.89)\end{array}$ & $\begin{array}{l}-0.447^{* *} \\
(-2.18)\end{array}$ \\
\hline I_FIRM & $\gamma_{1}$ & & $\begin{array}{l}-0.025^{* *} \\
(-2.46)\end{array}$ & & $\begin{array}{l}-0.0001^{*} \\
(-1.79)\end{array}$ & $\begin{array}{l}-0.027^{* * *} \\
(-3.30)\end{array}$ \\
\hline I_INCOME & $\gamma_{3}$ & & $\begin{array}{l}0.096^{* * *} \\
(2.41)\end{array}$ & & $\begin{array}{l}0.0005^{* *} \\
(1.99)\end{array}$ & $\begin{array}{l}0.131^{* *} \\
(2.11)\end{array}$ \\
\hline$\sigma \mathrm{IPO}_{(30 \text { after })}$ & & $\begin{array}{l}4.834^{* * * *} \\
(8.03)\end{array}$ & $\begin{array}{l}4.809^{* * *} \\
(8.86)\end{array}$ & & & $\begin{array}{l}4.851^{* * * *} \\
(7.58)\end{array}$ \\
\hline$\sigma \mathrm{m}_{(60 \text { before })}$ & & $\begin{array}{l}-2.342 \\
(-0.58)\end{array}$ & $\begin{array}{l}-2.717 \\
(-0.60)\end{array}$ & & & $\begin{array}{l}-0.967 \\
(-0.21)\end{array}$ \\
\hline REVISION & & $\begin{array}{l}0.001 \\
(1.36)\end{array}$ & $\begin{array}{l}0.001 \\
(1.33)\end{array}$ & & & $\begin{array}{l}0.001 \\
(1.22)\end{array}$ \\
\hline RANGE & & $\begin{array}{l}0.092 \\
(0.79)\end{array}$ & $\begin{array}{l}0.088 \\
(0.76)\end{array}$ & & & $\begin{array}{l}0.122 \\
(0.89)\end{array}$ \\
\hline REPUTATION & & $\begin{array}{l}0.034 \\
(0.47)\end{array}$ & $\begin{array}{l}0.009 \\
(0.13)\end{array}$ & & & $\begin{array}{l}0.012 \\
(0.14)\end{array}$ \\
\hline INSTITUTIONAL & & $\begin{array}{l}0.077 \\
(1.57)\end{array}$ & $\begin{array}{l}0.076^{* * *} \\
(2.10)\end{array}$ & & & $\begin{array}{l}0.065^{*} \\
(1.95)\end{array}$ \\
\hline PARTICIPATION RATIO & & $\begin{array}{l}-0.080 \\
(-1.13)\end{array}$ & $\begin{array}{l}-0.089 \\
(-1.50)\end{array}$ & & & $\begin{array}{l}-0.094 \\
(-1.52)\end{array}$ \\
\hline DILUTION FACTOR & & $\begin{array}{l}-0.151^{* * *} \\
(-3.01)\end{array}$ & $\begin{array}{l}-0.152^{* * *} \\
(-2.73)\end{array}$ & & & $\begin{array}{l}-0.152^{* * *} \\
(-2.67)\end{array}$ \\
\hline LN(1 + PROCEEDS) & & $\begin{array}{l}-0.013 \\
(-0.61)\end{array}$ & $\begin{array}{l}-0.009 \\
(-0.37)\end{array}$ & & & $\begin{array}{l}0.007 \\
(0.28)\end{array}$ \\
\hline LN(1 + FIRM AGE) & & $\begin{array}{l}-0.005 \\
(-0.38)\end{array}$ & $\begin{array}{l}-0.005 \\
(-0.48)\end{array}$ & $\begin{array}{l}-0.0002^{* * *} \\
(-5.14)\end{array}$ & $\begin{array}{l}-0.0002^{* * *} \\
(-5.47)\end{array}$ & $\begin{array}{l}-0.005 \\
(-0.29)\end{array}$ \\
\hline LN(FIRM SIZE) & & $\begin{array}{l}0.023 \\
(1.16)\end{array}$ & $\begin{array}{l}0.023 \\
(1.15)\end{array}$ & $\begin{array}{l}0.0002^{* * * *} \\
(10.66)\end{array}$ & $\begin{array}{l}0.0002^{* * *} \\
(11.53)\end{array}$ & $\begin{array}{l}0.010 \\
(0.56)\end{array}$ \\
\hline INDUSTRY MARKET-TO-BOOK & & & & $\begin{array}{l}0.0001^{* * * *} \\
(5.92)\end{array}$ & $\begin{array}{l}0.0001^{* * * *} \\
(5.11)\end{array}$ & \\
\hline ROA & & & & $\begin{array}{l}-0.0001 \\
(-0.50)\end{array}$ & $\begin{array}{l}-0.0001 \\
(-0.57)\end{array}$ & \\
\hline DEBT-TO-ASSET & & & & $\begin{array}{l}0.001^{* * * *} \\
(5.86)\end{array}$ & $\begin{array}{l}0.001^{* * * *} \\
(5.32)\end{array}$ & \\
\hline$\lambda$ & $\lambda$ & & & & & $\begin{array}{l}0.004 \\
(0.19)\end{array}$ \\
\hline Observations & & 137 & 137 & 60,002 & 60,002 & 137 \\
\hline Adjusted $R$-squared (Pseudo $R$-squared) & & 0.69 & 0.70 & $(0.24)$ & $(0.23)$ & 0.71 \\
\hline$F$-test $\left(\chi^{2}\right.$-test $)$ & & $9.782^{* * *}$ & $8.647^{* * *}$ & $\left(720.7^{* * *}\right)$ & $\left(739.9^{* * *}\right)$ & $8.250^{* * *}$ \\
\hline
\end{tabular}

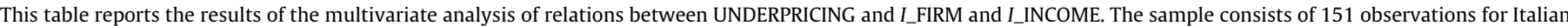

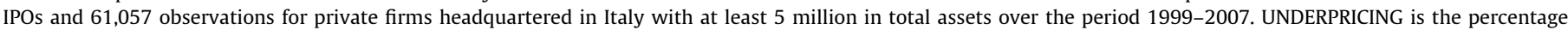

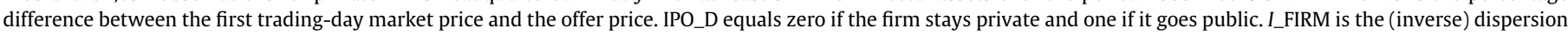

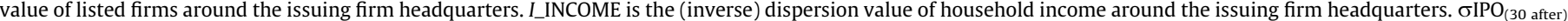

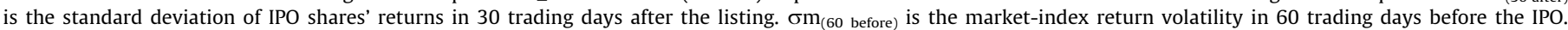

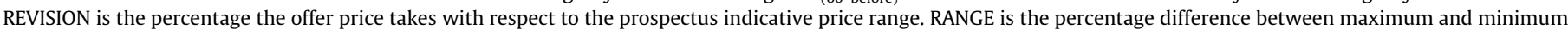

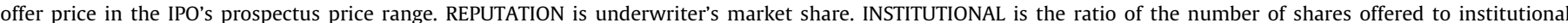

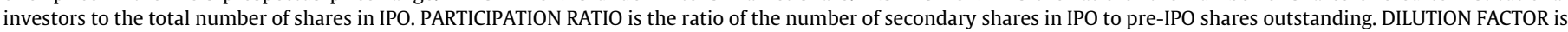

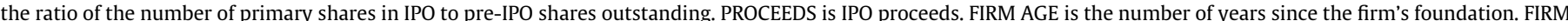

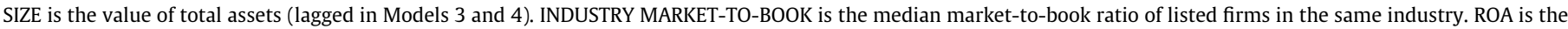

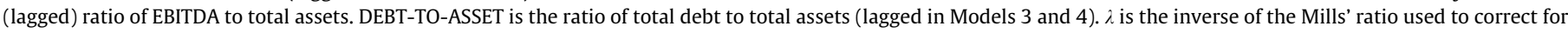
self-selection bias (Heckman, 1979). The $t$-statistics based on standard errors clustered by year and sub-sector are reported in parentheses.

* Statistical significance at the $10 \%$ level

** Statistical significance at the $5 \%$ level.

*** Statistical significance at the $1 \%$ level.

importantly, $\delta_{4}$ is not significantly different from $\gamma_{1}$, which is the effect of I_FIRM on LN(MARKET-TO-BOOK) ( $\chi^{2}$-test $=0.94$, $p$-value $=0.33)$. Furthermore, the pattern of the control variables is as expected and unchanged. Overall, this evidence strongly supports the consistency of I_FIRM ${ }^{\mathrm{CL}}$.

When variations of I_FIRM ${ }^{\mathrm{CL}}$ are addressed, the relation between I_FIRM $\mathrm{CL}_{t-1}^{\mathrm{CL}}$ and LN(MARKET-TO-BOOK) is negative and significant (Model 2: $\zeta_{1}=-0.054, p$-value $<0.05$ ) as predicted. On the other hand, the relations of $I_{-}$FIRM $_{\Delta t}^{\mathrm{CL}}$ and $I_{-}$FIRM $_{t-1}^{\mathrm{CL}} \times I_{-}$FIRM $_{\Delta t}^{\mathrm{CL}}$ with LN(MARKET-TO-BOOK) are not statistically significant (Model 2: $\zeta_{2}=-0.037, p$-value $>0.10 ; \zeta_{3}=-0.001, p$-value $\left.>0.10\right)$. If they are significant when singularly addressed, this implies that the aggregation effect of IPOs on average counterbalances the isolation effect of delistings.

When the effects of local IPOs and local delistings are disentangled, the findings are as expected (cf. Model 3). Indeed, the LN(MARKET-TO-BOOK) of firms that are clustering because of local IPOs (UP_D = 1) decreases with $I_{-}$FIRM $_{t-1}^{\mathrm{CL}}$ (i.e., the former level of local clustering) and $I_{-}$FIRM $_{\Delta t}^{\mathrm{CL}}$ (i.e., the increase of local clustering caused by local IPOs); in addition, LN(MARKET-TO-BOOK) increases with $I_{-} \mathrm{FIRM}_{t-1}^{\mathrm{CL}} \times I_{-} \mathrm{FIRM}_{\Delta t}^{\mathrm{CL}}$, meaning that the higher the level of clustering, the lower is the value-decreasing effect of the local IPOs (Model 3: $\zeta_{4}=-1.690, p$-value $<0.01 ; \zeta_{5}=-1.693$, $p$-value $<0.01 ; \zeta_{6}=1.618, p$-value $\left.<0.01\right)$. Interestingly, UP_D is 
Table 6

Robustness check.

\begin{tabular}{|c|c|c|c|c|c|c|}
\hline \multirow[t]{2}{*}{ Independent variables } & & \multicolumn{5}{|c|}{ Dependent variable: LN(MARKET-TO-BOOK) } \\
\hline & & $\begin{array}{l}\text { R\&D-TO-SALES } \\
(1)\end{array}$ & $\begin{array}{l}\text { NORTHEAST } \\
(2)\end{array}$ & $\begin{array}{l}\text { NORTHWEST } \\
(3)\end{array}$ & $\begin{array}{l}\text { SOUTH \& CENTER } \\
(4)\end{array}$ & $\begin{array}{l}\text { LOCAL GDP } \\
\text { (5) }\end{array}$ \\
\hline Constant & & $\begin{array}{l}0.834^{* *} \\
(2.37)\end{array}$ & $\begin{array}{l}-1.316 \\
(-1.45)\end{array}$ & $\begin{array}{l}0.323 \\
(0.70)\end{array}$ & $\begin{array}{l}2.276^{* *} \\
(2.42)\end{array}$ & $\begin{array}{l}0.950 \\
(1.60)\end{array}$ \\
\hline I_FIRM & $\gamma_{1}$ & $\begin{array}{l}-0.077^{* * *} \\
(-3.21)\end{array}$ & $\begin{array}{l}-0.235^{* *} \\
(-2.23)\end{array}$ & $\begin{array}{l}-0.140^{* *} \\
(-1-1.99)\end{array}$ & $\begin{array}{l}-0.402^{*} \\
(-1.67)\end{array}$ & $\begin{array}{l}-0.072^{* *} \\
(-2.84)\end{array}$ \\
\hline I_INCOME & $\gamma_{3}$ & $\begin{array}{l}0.272^{* * *} \\
(3.62)\end{array}$ & $\begin{array}{l}1.543^{* * * *} \\
(3.89)\end{array}$ & $\begin{array}{l}0.388^{*} \\
(1.69)\end{array}$ & $\begin{array}{l}0.562^{*} \\
(1.74)\end{array}$ & $\begin{array}{l}0.306^{* * *} \\
(3.67)\end{array}$ \\
\hline DEBT-TO-ASSET & & $\begin{array}{l}0.276 \\
(1.38)\end{array}$ & $\begin{array}{l}0.587^{*} \\
(1.91)\end{array}$ & $\begin{array}{l}0.008 \\
(0.04)\end{array}$ & $\begin{array}{l}0.368 \\
(1.11)\end{array}$ & $\begin{array}{l}0.296 \\
(1.50)\end{array}$ \\
\hline LN( 1 + PRESS COVERAGE $)$ & & $\begin{array}{l}0.280^{* * * *} \\
(7.04)\end{array}$ & $\begin{array}{l}0.430^{* * * *} \\
(6.93)\end{array}$ & $\begin{array}{l}0.195^{* * *} \\
(6.42)\end{array}$ & $\begin{array}{l}0.215^{* * *} \\
(3.59)\end{array}$ & $\begin{array}{l}0.276^{* * * *} \\
(7.98)\end{array}$ \\
\hline LN(1 + FIRM AGE) & & $\begin{array}{l}-0.097 \\
(-1.56)\end{array}$ & $\begin{array}{l}-0.017 \\
(-0.29)\end{array}$ & $\begin{array}{l}-0.116^{* * *} \\
(-3.66)\end{array}$ & $\begin{array}{l}-0.148^{* * * *} \\
(-2.65)\end{array}$ & $\begin{array}{l}-0.092 \\
(-1.54)\end{array}$ \\
\hline CAPEX-TO-ASSET & & & $\begin{array}{l}0.053 \\
(0.09)\end{array}$ & $\begin{array}{l}-0.400 \\
(-1.15)\end{array}$ & $\begin{array}{l}-0.050 \\
(-0.10)\end{array}$ & $\begin{array}{l}0.324 \\
(1.27)\end{array}$ \\
\hline R\&D-TO-SALES & & $\begin{array}{l}1.295^{* *} \\
(2.37)\end{array}$ & & & & \\
\hline ROE & & $\begin{array}{l}0.362^{* *} \\
(2.36)\end{array}$ & $\begin{array}{l}0.136 \\
(0.48)\end{array}$ & $\begin{array}{l}0.534^{* * *} \\
(3.46)\end{array}$ & $\begin{array}{l}-0.131 \\
(-0.82)\end{array}$ & $\begin{array}{l}0.348^{* *} \\
(2.22)\end{array}$ \\
\hline LN(FIRM SIZE) & & $\begin{array}{l}-0.095^{* * *} \\
(-3.06)\end{array}$ & $\begin{array}{l}-0.169^{* * *} \\
(-3.97)\end{array}$ & $\begin{array}{l}-0.033 \\
(-1.21)\end{array}$ & $\begin{array}{l}-0.153^{* * * *} \\
(-2.89)\end{array}$ & $\begin{array}{l}-0.080^{* * *} \\
(-2.40)\end{array}$ \\
\hline LN(1 + LOCAL GDP) & & & & & & $\begin{array}{l}-10.308 \\
(-0.35)\end{array}$ \\
\hline Observations & & 1306 & 319 & 747 & 295 & 1148 \\
\hline Adjusted $R$-squared & & 0.45 & 0.54 & 0.54 & 0.62 & 0.46 \\
\hline
\end{tabular}

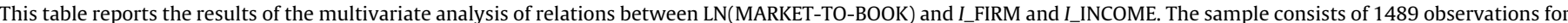

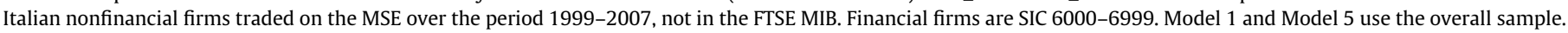

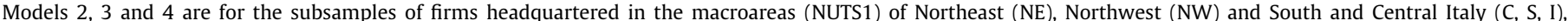

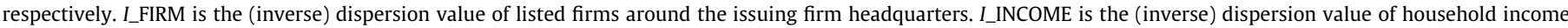

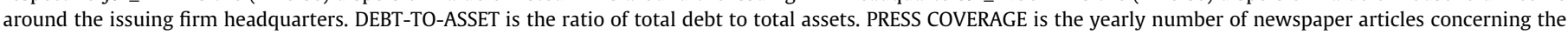

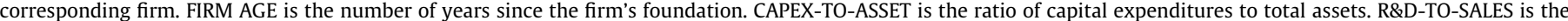

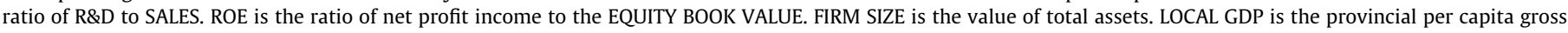

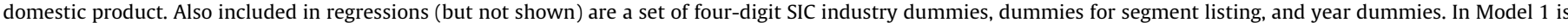

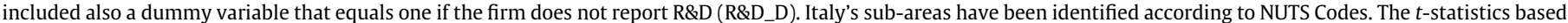
on standard errors clustered by firm and year are reported in parentheses.

* Statistical significance at the $10 \%$ level.

** Statistical significance at the $5 \%$ level.

**** Statistical significance at the $1 \%$ level.

positively and significantly related with LN(MARKET-TO-BOOK) (Model 3: $\zeta_{U P}=1.602, p$-value $<0.01$ ), meaning that, all other things being equal, firms facing local IPOs trade at a premium. Consistently, the pattern is specular when the effect of local delistings (DOWN_D = 1) is addressed. The relations of $I_{-} \mathrm{FIRM}_{t-1}^{\mathrm{CL}}$, $I_{-}$FIRM $_{\Delta t}^{\mathrm{CL}}$, and I_FIRM ${ }_{t-1}^{\mathrm{CL}} \times I_{-}$FIRM $_{\Delta t}^{\mathrm{CL}}$ with LN(MARKET-TO-BOOK) are negative, positive, and negative, respectively (Model 3: $\zeta_{7}=-0.482, p$-value $<0.05 ; \zeta_{8}=1.618, p$-value $<0.01 ; \zeta_{9}=-0.430$, $p$-value $<0.01)$, meaning that for firms that are becoming more isolated due to local delistings, the market value decreases with the initial level of local clustering and increases with a decreasing number of local listed firms remaining after the local delistings. Furthermore, the value-enhancing effect of local delistings weakens the higher the former level of local clustering. Finally, DOWN_D is also positively and significantly related with LN(MARKET-TO-BOOK) (Model 3: $\zeta_{\text {Down }}=1.599, p$-value $<0.01$ ), meaning that, all other things being equal, firms facing local delistings also trade at a premium.

Economically, now consider the isolated firms for which I_FIRM ${ }^{\mathrm{CL}}$ equals 1 . In addition, suppose that because of local IPOs, the value of $I_{-}$FIRM ${ }^{\mathrm{CL}}$ rises to 2 (i.e., $I_{-} \mathrm{FIRM}_{t-1}^{\mathrm{CL}}=1, I_{-} \mathrm{FIRM}_{\Delta t}^{\mathrm{CL}}=1$ and UP_D $=1$ ). Our results imply a negative variation of the LHB effect and thus of the location premium, which is equal to $-7.23 \%$. Notably, the estimated variation in LN(MARKET-TO-BOOK) is $-0.075(-0.075=-1.693 \times(2-1)+1.618 \times(2-1) \times 1)$, which corresponds to a variation of MARKET-TO-BOOK of $-7.23 \%$ $\left(-0.0723=\mathrm{e}^{(-0.075)}-1\right)$. However, if due to more intense local
IPO activity the same isolated firm clusters up to values of I_FIRM ${ }^{\mathrm{CL}}$ of 3 or 4, the MARKET-TO-BOOK variations are estimated to equal $-13.93 \%$ and $-20.15 \%$, respectively. Similarly, the clustered firm (i.e., $I_{-}$FIRM ${ }^{\mathrm{CL}}=4$ ) that is becoming more isolated because of local delistings experiences positive variations in the LHB effect and ultimately of the location premium, which are estimated at $35.80 \%$, $22.63 \%$, and $10.74 \%$ if the prospective level of clustering is equal to 1,2 , and 3 , respectively.

\section{Local clustering and IPO underpricing}

In this section, we test the significance of the relation between UNDERPRICING and I_FIRM and I_INCOME. We predict I_FIRM negatively affects UNDERPRICING, while $I_{-} I N C O M E$ is expected to positively affect UNDERPRICING (i.e., $\gamma_{1}<0$ and $\gamma_{3}>0$ ). Table 5 reports the results. Model 1 is the baseline specification for UNDERPRICING. Model 2 adds I_FIRM and I_INCOME. Model 3 and 4 test the likelihood of going public. Finally, Model 5 tests the UNDERPRICING controlling for self-selection bias.

As predicted, UNDERPRICING is negatively affected by I_FIRM (Model 2: $\gamma_{1}=-0.025, p$-value $<0.05$ ) and positively affected by I_INCOME (Model 2: $\gamma_{3}=0.096, p$-value $<0.05$ ). In addition, the pattern of the control variables is as expected. Model 3 and 4 test the listing decision: In particular, Model 4 shows the likelihood of going public is negatively related to I_FIRM (Model 4: $\gamma_{1}=-0.0001$, $p$-value $<0.10$ ) and positively related to I_INCOME (Model 4: 
Table A.1

Data sources.

\begin{tabular}{|c|c|c|}
\hline Data source & Url & Data collected \\
\hline \multicolumn{3}{|l|}{ Household level } \\
\hline ISTAT & www.istat.it & Household disposable income and resident population at region level \\
\hline Rapporto Unioncamere & www.unioncamere.it & Household disposable income and resident population at province level \\
\hline \multicolumn{3}{|l|}{ Firm level } \\
\hline Consob & www.consob.it & List of all firms issuing securities listed on the MSE over the period 1999-2007 \\
\hline Osiris & https://osiris.bvdep.com & Location (Address, City, Province, ZIP code) of the headquarters of each sampled firm \\
\hline Company Annual Report & www.borsaitaliana.it \& company website & Location (Address, City, Province, ZIP code) of the headquarters of each sampled firm \\
\hline Borsa Italiana S.p.A. & www.borsaitaliana.it & $\begin{array}{l}\text { List updated at the end of the last working day of each year over the period 1999-2007 } \\
\text { of: (i) securities not actively traded on the MSE and (ii) securities traded on the MSE } \\
\text { included in the FTSE MIB Index; IPO prospectus and data }\end{array}$ \\
\hline Amadeus & https://amadeus.bvdinfo.com & List of all private firms headquartered in Italy and private firms data \\
\hline Il Sole 24 Ore & www.ilsole24ore.com & Firm press coverage: number of articles \\
\hline Il Calepino dell'Azionista & $\begin{array}{l}\text { www.mbres.it/it/publications/ } \\
\text { calepino-dellazionista }\end{array}$ & Year of firm foundation \\
\hline Datastream \& Worldscope & www.thomsonone.com & Financial and accounting information \\
\hline Eurostat & http://epp.eurostat.ec.europa.eu & NUTS Codes \\
\hline
\end{tabular}

$\gamma_{3}=0.0005, p$-value $\left.<0.05\right)$. Therefore, firm location related factors even affect the decision to go public.

Our results on UNDERPRICING are confirmed even controlling for self-selection bias. ${ }^{3}$ When Heckman's $\lambda$ is included among the explanatory variables, the effect of I_FIRM on UNDERPRICING remains negative and highly statistically significant (Model 5: $\gamma_{1}=-0.027, \quad p$-value $\left.<0.01\right)$, while the effect of $I$ INCOME on UNDERPRICING is positive and significant (Model 5: $\gamma_{3}=0.131$, $p$-value $<0.05)$. Overall this evidence suggests that even though location specific factors drive the listing decision, the LHB effect is (at least partly) underestimated in the IPO price-setting process as IPOs located in areas with higher income clustering and lower concentration of local listed firms exhibit larger underpricing.

From an economic point of view, when I_FIRM goes from the 25th to 75 th percentile (from 1.630 to 3.811 ), our results indicate a negative variation of the LHB effect and a variation in the UNDERPRICING equal to $-5.89 \%$. On the other hand, same variation for I_INCOME (from 1.899 to 2.283 ) results in a positive change in UNDERPRICING equal to $5.02 \%$.

\section{Robustness checks}

In this section, we provide the results from a series of additional robustness checks. Table 6 displays the results.

In Model 1, we replicate the analysis of Table 3 using as a proxy for growth opportunities R\&D-TO-SALES as in HKS instead of CAPEX-TO-ASSET. Although not shown, we also include a dummy variable (R\&D_D) that equals one if the company does not report R\&D expenditure (R\&D) and zero otherwise (e.g., Chan et al., 2001; HKS). Findings are unchanged with respect to previous results.

Socioeconomic characteristics in Italy vary drastically by geographical areas. For instance, per capita GDP and the level of unemployment are sharply different between northern and southern Italy (e.g., Guiso et al., 2004). These differences likely have a significant effect on MARKET-TO-BOOK and firm and investor income clustering. To control for local socioeconomic characteristics, we replicate the analysis of Table 3 on the subsamples of firms headquartered in the macroareas of Northeast (Model 2), Northwest (Model 3), and South and Central Italy (Model 4). In Model 5, as a further check, we also replicate the analysis of Table 3

\footnotetext{
${ }^{3}$ Results are based on outcomes of Model 4. However, findings are unchanged when based on Model 3 (not reported).
}

by introducing the control variable for provincial per capita GDP (LOCAL GDP). Once again, the main findings are unchanged.

\section{Conclusions}

The notion that geographic traits affect firm value is well established in the economics, finance, and management literature. However, only peripheral empirical evidence about causation has been produced so far. Borrowing a measure (used in ecology) to synthesize the attributes of firm geographic location, this paper provides evidence of a firm location premium that is dynamically affected by local IPOs and delistings.

We estimate that listed firms benefit from a location premium that is approximately 0.7 of their market-to-book and increases with the Local Home Bias (LHB) and local investor risk tolerance. More broadly, the corporate market value increases with the distance of any given firm to other listed firms and increases almost twofold in proximity to high investor income. Remarkably, we find that local IPOs and delistings consistently affect the market value of listed firms. For instance, we estimate that the location premium of highly isolated (clustered) firms decreases (increases) by as much as $20 \%$ (35\%) because of the aggregation (isolation) effect of local IPOs (delistings). In the same vein, we find IPO underpricing also drops with firm proximity to other listed firms and increases in proximity to investor income: the first-day return of clustered IPOs is, on average, 6\% lower than the first-day return of the isolated IPOs.

Our findings also furnish new evidence that arguably represents a call for future research. For instance, firms facing significant local IPOs or delisting activity trade at a premium. This evidence seems consistent with a sort of value-enhancing-environment effect. Conceivably, while IPOs are in developing areas with conditions favoring economic growth (e.g., high-quality infrastructure, access to a deeper and higher quality labor pool, etc.), delistings are in disinvesting areas that have met the same positive conditions so far. All other things being equal, firms benefitting from valuable environmental conditions, trade at a premium.

The financial research is enriched by the introduction of measures of firm exposure to LHB and investor risk tolerance, and the empirical findings add to the asset-pricing, IPOs, and going private transactions literature. Finally, firms can be equated to living organisms in their grueling attempt to successfully interact with each other and with the environment they live into survive, so it follows that measurement instruments used in the field of ecology become useful tools for future contributions in financial research. 
Table A.2

Variable definitions.

\begin{tabular}{|c|c|}
\hline Variable & Description \\
\hline$\sigma \mathrm{IPO}_{(30}$ after $)$ & The standard deviation of IPO shares' returns in 30 trading days after the listing. Source: Datastream (datatype: RI) \\
\hline$\sigma \mathrm{m}_{(60 \text { before })}$ & The market-index return volatility in 60 trading days before the IPO. Source: Datastream (datatype: RI) \\
\hline$\lambda$ & Inverse of the Mills' ratio used to correct for self-selection bias (Heckman, 1979). \\
\hline CAPEX-TO-ASSET & The ratio of capital expenditures (Worldscope datatype: WC04601) to total assets (Worldscope datatype: WC02999). \\
\hline DEBT-TO-ASSET & The ratio of total debt (Worldscope datatype: WC03255) to total assets (Worldscope datatype: WC02999). \\
\hline DILUTION FACTOR & The ratio of the number of primary shares in IPO to pre-IPO shares outstanding. Source: Borsa Italiana \\
\hline DISPOSABLE INCOME & $\begin{array}{l}\text { The household disposable income } \\
\text { It is computed as follows: } \\
\text { DISPOSABLE INCOME = Primary Income - Current Taxes - Social Contributions + Social Benefits + Other Net Transfers } \\
\text { where: } \\
\text { Primary Income = Gross Operating Surplus + Gross Mixed Income + Income from Employment + Financial Income (Equity } \\
\text { Income + Non-Equity Income). } \\
\text { Source: ISTAT }\end{array}$ \\
\hline
\end{tabular}

DISTANCE

The shortest spherical distance between two points on the Earth's surface in kilometers.

Formally, let $\left(\theta_{s}, \lambda_{s}\right)$ and $\left(\theta_{f}, \lambda_{f}\right)$ be the geographical latitude and longitude of two points, a base standpoint $S$ and the destination fore point $\mathrm{F}$, respectively. The DISTANCE $d_{s, f}$ between $\mathrm{S}$ and $\mathrm{F}$ is computed as:

$d_{s, f}=\operatorname{arc} \cos \left\{\cos \left(\operatorname{lon}_{s}-\operatorname{lon}_{f}\right)^{*} \cos \left(\operatorname{lat}_{s}\right)^{*} \cos \left(\right.\right.$ lat $\left._{f}\right)+\sin \left(l_{\text {lat }}\right)^{*} \sin \left(\right.$ lat $\left.\left._{f}\right)\right\} * 2 \pi r / 360$

where:

$r$ is the radius of the earth $(\approx 6378 \mathrm{~km})$

DOWN_D

EQUITY BOOK VALUE EQUITY MARKET VALUE

FIRM AGE

FIRM SIZE

FTSE_D

(NON-)FTSE-FIRMS

$I$

I_FIRM

I_FIRM ${ }^{\mathrm{CL}}$

$I_{-} \mathrm{FIRM}_{\Delta t}^{\mathrm{CL}}$

$I_{-}$FIRM $_{t-1}^{\mathrm{CL}}$

I_FIRM ${ }^{\text {CLN }}$

I_FIRM $M_{Y E A R}^{C L N^{*}}$

I FIRM

I_INCOME
Equal to one if $I_{-}$FIRM $_{\Delta t}^{\mathrm{CL}}$ is lower than zero and zero otherwise

Book value of common equity. Source: Worldscope (datatype: WC03501)

Market value of common equity. Source: Worldscope (datatype: WC08001).

The number of years of a firm's life since foundation. Source: Il Calepino dell'Azionista.

Total assets. Source: Worldscope (datatype: WC02999).

Equal to one if the firm is included in the Italian equity market primary index (FTSE MIB Index) and zero otherwise. Source: Borsa Italiana.

Firm-year observations for which FTSE_D is (not) equal to one.

The Johnson and Zimmer index of dispersion.

Formally, given the two-dimensional Euclidean space $\mathrm{E}^{2}$, let the generic point $i$ and a sample of $r$ random points in $\mathrm{E}^{2}$, all individuated by the latitude and longitude geographical coordinates, the Johnson and Zimmer dispersion index I for the point $i$ is computed as:

$I=\frac{(r+1) \sum_{r=1 k r \neq i}^{r}\left(d_{i, r}^{4}\right)}{\left[\sum_{r=1 k r \neq i}^{r}\left(d_{i, r}^{2}\right)\right]^{2}}$

where:

$d_{i, r}$ is the DISTANCE between the point $i$ and each of the $r$-points.

The expected value of I has a value approaching two for a random distribution, lower than two for scattered distribution, and higher than two for an aggregated distribution.

In the weighted version of I, $d_{i, r}$ in the numerator has to be multiplied by $w_{i, r}^{2}$, while $d_{i, r}$ in the denominator is multiplied by $w_{i, r}$, where: $w_{i, r}$ is the weight of $d_{i, r}$

The yearly Johnson and Zimmer dispersion index computed on the geographical locations (i.e., latitude and longitude) of the issuing firm headquarters and the headquarters of all other sampled listed firms

The four-clustered-based version of the I_FIRM variable (i.e., I_FIRM ${ }^{\mathrm{CL} 4}$ ). It takes values in the range 1:4, which defines the number of clusters to which each firm-year observation belongs; the higher the cluster value is, the higher the within-cluster average value of I_FIRM

The first difference of $I_{-}$FIRM $^{\mathrm{CL}}$

The first lag of $I_{-}$FIRM $^{\mathrm{CL}}$

The set of our 10 clustered versions of the I_FIRM variable, depending on the number of clusters in which observations are grouped. $I_{-}$FIRM $^{\mathrm{CLN}}$ variables have been obtained by matching over YEAR for each value of $N$ I_FIRM $\mathrm{CLAR}_{\text {YEA }}^{\mathrm{C}}$ variables. The generic clustered version of the $I \_F I R M$ variable, $I \_F I R M^{\mathrm{CLN} N}$, is defined for all sampled firm-year observations, takes values in the range $1: N$, and defines the number of the clusters to which each firm-year observation belongs. Clusters are ranked in ascending order according to the average value within-cluster of $I$ IFIRM

The set of 90 variables obtained from I_FIRM ascending order according to the within-cluster average value of I_FIRM; (ii) the clusters have been consistently re-coded

The set of 90 variables obtained from clustering the year-by-year sampled firm-year observations on the basis of the value of the I_FIRM variable, using (i) hierarchical clustering, (ii) the average clustering linkage method, and (iii) the absolute-value distance (the Minkowski distance metric with argument one) as a (dis)similarity measure

The generic I_FIRM $\mathrm{CLN}$ Variable is defined only in the respective YEAR and assumes values in the range 1: N,

where:

YEAR $=1999,2000, \ldots, 2007$, and $N=1,2, \ldots, 10$ is the number of clusters in which firm-year observations have been grouped

The yearly weighted Johnson and Zimmer dispersion index computed on geographical locations (i.e., latitude and longitude) of the issuing firm headquarters and all provincial capital cities, with weights equal to the normalized provincial per capita DISPOSABLE INCOME 
Table A.2 (continued)

\begin{tabular}{|c|c|}
\hline Variable & Description \\
\hline INDUSTRY MARKET-TO-BOOK & The median market-to-book ratio of listed firms in the same industry. Source: Amadeus \\
\hline INSTITUTIONAL & The ratio of the number of shares offered to institutional investors to the total number of shares in IPO. Source: Borsa Italiana \\
\hline IPO_D & Equal to zero if the firm stays private and one if it goes public. Source: Amadeus \\
\hline LOCAL GDP & The provincial per capita gross domestic product. Source: ISTAT \\
\hline MARKET-TO-BOOK & The ratio of EQUITY MARKET VALUE to EQUITY BOOK VALUE \\
\hline PARTICIPATION RATIO & The ratio of the number of secondary shares in IPO to pre-IPO shares outstanding. Source: Borsa Italiana \\
\hline PRESS COVERAGE & The yearly number of newspaper articles concerning the corresponding firm. Source: Il Sole 24 Ore \\
\hline PROCEEDS & IPO proceeds. Source: Borsa Italiana \\
\hline RANGE & The percentage difference between maximum and minimum offer price in the IPO's prospectus price range. Source: Borsa Italiana \\
\hline RATIO & $\begin{array}{l}\text { The ratio of the EQUITY BOOK VALUE of all listed firms headquartered in a given geographical area to the DISPOSABLE INCOME of all } \\
\text { households living in the same geographical area } \\
\text { Formally, considering at year } t \text { an economy where } I \text { listed firms and } k \text { households are located in the region } j \text {, the RATIO for region } j \text { is } \\
\text { computed as: } \\
R A T I O_{j, t}=\sum_{i} B V_{i, j, t} \\
\text { where: } \\
B V_{i, j, t} \text { is the EQUITY BOOK VALUE of the listed firm } i \text { headquartered in the region } j \text { in the year } t \text {, and } D I_{k, j} \text { is the DISPOSABLE INCOME of } \\
\text { the household } k \text { living in the region } j \text { in the year } t\end{array}$ \\
\hline REPUTATION & Underwriter's market share. Source: Borsa Italiana \\
\hline REVISION & The percentage the offer price takes with respect to the prospectus indicative price range. Source: Borsa Italiana \\
\hline $\mathrm{R} \& \mathrm{D}$ & Research and development expense. Source: Worldscope (datatype: WC01201) \\
\hline R\&D_D & Equal to one if the firm does not report R\&D and zero otherwise \\
\hline R\&D-TO-SALES & The ratio of R\&D to SALES \\
\hline ROA & The ratio of EBITDA to total assets. Source: Amadeus \\
\hline ROE & The ratio of the firm net profit income to the EQUITY BOOK VALUE. Source: Datastream (datatype: DWRE) \\
\hline SALES & Net sales or revenues. Source: Worldscope (datatype: WC01001) \\
\hline SOE_D & $\begin{array}{l}\text { Equal to one if the firm's largest ultimate owner is the Italian government, a local authority (county, municipality, etc.), or a } \\
\text { government agency and zero otherwise. Source: database used in Pazzaglia et al. (2013) }\end{array}$ \\
\hline UNDERPRICING & The percentage difference between the first trading-day market price and the offer price. Source: Borsa Italiana \\
\hline UP_D & Equal to one if $I_{-} \mathrm{FIRM}_{\Delta t}^{\mathrm{CL}}$ is greater than zero and zero otherwise \\
\hline
\end{tabular}

\section{Acknowledgments}

For their comments and suggestions, we would like to thank the two anonymous referees, Tom Aabo, Charles Baden-Fuller, Marco Bigelli, David Hirshleifer, Henry Lahr, Martin Martens, Jennifer Monroe, Holger Mueller, Michael Roberts, Sandro Sandri, William (Bill) Schwert, and Qunzi Zhang, as well as the participants at the Mathematical and Statistical Methods for Actuarial Sciences and Finance Annual Conference (April 2012) and the European Financial Management Association Annual Conference (June 2012). The views expressed herein are those of the authors, and we alone bear responsibility for any mistakes and inaccuracies.

\section{Appendix A. Data sources and variables definition}

See Tables A.1 and A.2.

\section{Appendix B. Cluster analysis and selection of I_FIRM ${ }^{C L}$}

Cluster analysis determines the natural groupings (or clusters) of a set of observations on the basis of the characteristics (variables) they possess, seeking to minimize the within-group variance and to maximize the between-group variance. To perform a cluster analysis, (i) the type of clustering, either hierarchical or partition, (ii) the clustering linkage method, which is the criterion used to compare the between-groups, and (iii) the measure of (dis) similarity, which is the criterion used to compare between observations, must be chosen (e.g., Kaufman and Rousseeuw, 1990; Everitt et al., 2011). We cluster observations upon I_FIRM using: (i) hierarchical clustering, (ii) the average clustering linkage method, and (iii) absolute-value distance (the Minkowski distance metric with argument one). For (ii) and (iii), we consider our results robust because the results remain unchanged when we re-run the analysis using almost all other available options. ${ }^{4}$ For (i), we prefer hierarchical clustering to partition clustering to avoid introducing exogenous elements. Indeed, in partition clustering, the number of clusters is exogenously pre-set; therefore, let us assume that this is equal to $N^{*}$ and that the output of cluster analysis is only one "clustered" variable assuming values from 1 to $N^{*}$, which is the number of the cluster to which each observation belongs. On the other hand, hierarchical clustering ideally creates as many clustered variables as the number of observations to be clustered, so let us assume that this is equal to $N$. Clustered variables take values 1 , from 1 to 2 , and so on, up to from 1 to $N$, depending on the number of clusters in which the $\mathrm{N}$-observations are endogenously grouped. Therefore, each clustered variable defines a different number of clusters. Afterwards, it is necessary to determine the optimal number of clusters $N^{*}$ and, accordingly, the clustered variable to consider. Within our framework, this means finding the levels of clustering of Italian listed firms to select the most proper clustered variable to replace I_FIRM.

\footnotetext{
${ }^{4}$ We also use (i) single linkage, complete linkage, weighted-average linkage, median linkage, centroid linkage, Ward's linkage, and (ii) Euclidean distance (Minkowski with argument two), squared Euclidean distance, maximum-value distance (Minkowski with infinite argument), Canberra distance, the correlation coefficient similarity measure, and the angular separation similarity measure. See Day and Edelsbrunner (1984); in addition, see Anderberg (1973) and Gordon (1999) for discussions on linkage methods and similarity measures, respectively.
} 
Table B.1

Selection of I_FIRM ${ }^{\mathrm{CL}}$ among I_FIRM ${ }^{\mathrm{CLN}}$ variables.

\begin{tabular}{|c|c|c|c|c|c|c|c|c|c|c|c|}
\hline \multicolumn{12}{|c|}{ Panel A - pairwise correlations } \\
\hline & & $\# 1$ & $\# 2$ & \#3 & $\# 4$ & \#5 & \#6 & \#7 & $\# 8$ & \#9 & $\# 10$ \\
\hline \#1 & I_FIRM & 1 & & & & & & & & & \\
\hline \#2 & I_FIRM ${ }^{\mathrm{CL} 2}$ & $0.8179^{*}$ & 1 & & & & & & & & \\
\hline \#3 & I_FIRM ${ }^{\mathrm{CL} 3}$ & $0.9302^{*}$ & $0.8733^{*}$ & 1 & & & & & & & \\
\hline \#4 & I_FIRM ${ }^{\mathrm{CL}}$ & $0.9411^{*}$ & $0.8534^{*}$ & $0.9826^{*}$ & 1 & & & & & & \\
\hline \#5 & I_FIRM ${ }^{\mathrm{CL} 5}$ & $0.9376^{*}$ & $0.8512^{*}$ & $0.9728^{*}$ & $0.9817^{*}$ & 1 & & & & & \\
\hline \#6 & I_FIRM ${ }^{\mathrm{CL6}}$ & $0.9399^{*}$ & $0.8520^{*}$ & $0.9732^{*}$ & $0.9794^{*}$ & $0.9950^{*}$ & 1 & & & & \\
\hline \#7 & I_FIRM ${ }^{\mathrm{CL} 7}$ & $0.9373^{*}$ & $0.8486^{*}$ & $0.9709^{*}$ & $0.9789^{*}$ & $0.9879^{*}$ & $0.9921^{*}$ & 1 & & & \\
\hline \#8 & I_FIRM ${ }^{\mathrm{CL8}}$ & $0.9331^{*}$ & $0.8462^{*}$ & $0.9666^{*}$ & $0.9706^{*}$ & $0.9851^{*}$ & $0.9856^{*}$ & $0.9888^{*}$ & 1 & & \\
\hline \#9 & I_FIRM ${ }^{\mathrm{CL} 9}$ & $0.9332^{*}$ & $0.8417^{*}$ & $0.9624^{*}$ & $0.9720^{*}$ & $0.9822^{*}$ & $0.9800^{*}$ & $0.9822^{*}$ & $0.9900^{*}$ & 1 & \\
\hline \#10 & I_FIRM ${ }^{\mathrm{CL} 10}$ & $0.9140^{*}$ & $0.8326^{*}$ & $0.9520^{*}$ & $0.9616^{*}$ & $0.9752^{*}$ & $0.9744^{*}$ & $0.9745^{*}$ & $0.9806^{*}$ & $0.9877^{*}$ & 1 \\
\hline \multicolumn{12}{|c|}{ Panel B - the effects of I_FIRM ${ }^{C L N}$ on MARKET-TO-BOOK } \\
\hline \multirow{2}{*}{\multicolumn{2}{|c|}{ Independent variables }} & & \multicolumn{9}{|c|}{ Dependent variable: LN(MARKET-TO-BOOK) } \\
\hline & & & (1) & $(2)$ & (3) & $(4)$ & (5) & (6) & (7) & (8) & (9) \\
\hline Cons & & & $\begin{array}{l}0.965^{*} \\
(2.02)\end{array}$ & $\begin{array}{l}0.837^{*} \\
(1.80)\end{array}$ & $\begin{array}{l}0.768 \\
(1.73)\end{array}$ & $\begin{array}{l}0.766 \\
(1.73)\end{array}$ & $\begin{array}{l}0.765^{*} \\
(1.75)\end{array}$ & $\begin{array}{l}0.736 \\
(1.69)\end{array}$ & $\begin{array}{l}0.717 \\
(1.64)\end{array}$ & $\begin{array}{l}0.715 \\
(1.63)\end{array}$ & $\begin{array}{l}0.705 \\
(1.63)\end{array}$ \\
\hline I_FIR & & $\delta_{2}$ & $\begin{array}{l}-0.058 \\
(-0.83)\end{array}$ & & & & & & & & \\
\hline I_FIR & & $\delta_{3}$ & & $\begin{array}{l}-0.063 \\
(-1.21)\end{array}$ & & & & & & & \\
\hline I_FIR & & $\delta_{4}$ & & & $\begin{array}{l}-0.055^{* *} \\
(-2.80)\end{array}$ & & & & & & \\
\hline I_FIR & & $\delta_{5}$ & & & & $\begin{array}{l}-0.037^{* *} \\
(-2.35)\end{array}$ & & & & & \\
\hline I_FIR & & $\delta_{6}$ & & & & & $\begin{array}{l}-0.030^{* *} \\
(-2.42)\end{array}$ & & & & \\
\hline I_FIR & & $\delta_{7}$ & & & & & & $\begin{array}{l}-0.028^{* *} \\
(-2.59)\end{array}$ & & & \\
\hline I_FIR & & $\delta_{8}$ & & & & & & & $\begin{array}{l}-0.025^{* *} \\
(-2.73)\end{array}$ & & \\
\hline I_FIR & & $\delta_{9}$ & & & & & & & & $\begin{array}{l}-0.023^{* *} \\
(-2.71)\end{array}$ & \\
\hline I_FIR & & $\delta_{10}$ & & & & & & & & & $\begin{array}{l}-0.021^{\text {*** }} \\
(-2.72)\end{array}$ \\
\hline I_INC & & & $\begin{array}{l}0.164^{* *} \\
(2.18)\end{array}$ & $\begin{array}{l}0.214^{* *} \\
(2.90)\end{array}$ & $\begin{array}{l}0.257^{\text {*** }} \\
(3.67)\end{array}$ & $\begin{array}{l}0.243^{* * * *} \\
(3.44)\end{array}$ & $\begin{array}{l}0.240^{* * *} \\
(3.44)\end{array}$ & $\begin{array}{l}0.252^{* * *} \\
(3.61)\end{array}$ & $\begin{array}{l}0.258^{* * * *} \\
(3.73)\end{array}$ & $\begin{array}{l}0.261^{* * *} \\
(3.71)\end{array}$ & $\begin{array}{l}0.267^{* * * *} \\
(3.82)\end{array}$ \\
\hline DEBT & ASSET & & $\begin{array}{l}0.249 \\
(1.28)\end{array}$ & $\begin{array}{l}0.242 \\
(1.26)\end{array}$ & $\begin{array}{l}0.247 \\
(1.30)\end{array}$ & $\begin{array}{l}0.240 \\
(1.23)\end{array}$ & $\begin{array}{l}0.241 \\
(1.24)\end{array}$ & $\begin{array}{l}0.241 \\
(1.25)\end{array}$ & $\begin{array}{l}0.240 \\
(1.23)\end{array}$ & $\begin{array}{l}0.239 \\
(1.23)\end{array}$ & $\begin{array}{l}0.239 \\
(1.24)\end{array}$ \\
\hline $\mathrm{LN}(1$ & ESS COVERAGE) & & $\begin{array}{l}0.275^{* * *} \\
(7.15)\end{array}$ & $\begin{array}{l}0.273^{\text {**** }} \\
(7.09)\end{array}$ & $\begin{array}{l}0.272^{* * * k} \\
(7.07)\end{array}$ & $\begin{array}{l}0.273^{* * *} \\
(7.09)\end{array}$ & $\begin{array}{l}0.273^{\text {*****at }} \\
(7.09)\end{array}$ & $\begin{array}{l}0.273^{\text {**** }} \\
(7.06)\end{array}$ & $\begin{array}{l}0.273^{* * * *} \\
(7.09)\end{array}$ & $\begin{array}{l}0.273^{* * *} \\
(7.13)\end{array}$ & $\begin{array}{l}0.273^{* * *} \\
(7.13)\end{array}$ \\
\hline $\mathrm{LN}(1$ & M AGE) & & $\begin{array}{l}-0.105 \\
(-1.73)\end{array}$ & $\begin{array}{l}-0.101 \\
(-1.67)\end{array}$ & $\begin{array}{l}-0.099 \\
(-1.63)\end{array}$ & $\begin{array}{l}-0.101 \\
(-1.67)\end{array}$ & $\begin{array}{l}-0.101 \\
(-1.67)\end{array}$ & $\begin{array}{l}-0.100 \\
(-1.64)\end{array}$ & $\begin{array}{l}-0.100 \\
(-1.64)\end{array}$ & $\begin{array}{l}-0.099 \\
(-1.64)\end{array}$ & $\begin{array}{l}-0.099 \\
(-1.63)\end{array}$ \\
\hline CAPE & -ASSET & & $\begin{array}{l}-0.125 \\
(-0.38)\end{array}$ & $\begin{array}{l}-0.098 \\
(-0.29)\end{array}$ & $\begin{array}{l}-0.102 \\
(-0.30)\end{array}$ & $\begin{array}{l}-0.105 \\
(-0.31)\end{array}$ & $\begin{array}{l}-0.100 \\
(-0.30)\end{array}$ & $\begin{array}{l}-0.099 \\
(-0.29)\end{array}$ & $\begin{array}{l}-0.101 \\
(-0.30)\end{array}$ & $\begin{array}{l}-0.095 \\
(-0.28)\end{array}$ & $\begin{array}{l}-0.093 \\
(-0.27)\end{array}$ \\
\hline ROE & & & $\begin{array}{l}0.348^{* *} \\
(2.22)\end{array}$ & $\begin{array}{l}0.345^{* *} \\
(2.18)\end{array}$ & $\begin{array}{l}0.346^{* *} \\
(2.19)\end{array}$ & $\begin{array}{l}0.341^{* *} \\
(2.14)\end{array}$ & $\begin{array}{l}0.342^{* * *} \\
(2.15)\end{array}$ & $\begin{array}{l}0.344^{* *} \\
(2.17)\end{array}$ & $\begin{array}{l}0.343^{* *} \\
(2.17)\end{array}$ & $\begin{array}{l}0.344^{* *} \\
(2.18)\end{array}$ & $\begin{array}{l}0.343^{* *} \\
(2.16)\end{array}$ \\
\hline $\mathrm{LN}(\mathrm{F}$ & SIZE) & & $\begin{array}{l}-0.091 \\
(-2.82)\end{array}$ & $\begin{array}{l}-0.088^{* *} \\
(-2.72)\end{array}$ & $\begin{array}{l}-0.088^{* *} \\
(-2.77)\end{array}$ & $\begin{array}{l}-0.087^{* *} \\
(-2.72)\end{array}$ & $\begin{array}{l}-0.087^{* *} \\
(-2.74)\end{array}$ & $\begin{array}{l}-0.087^{* *} \\
(-2.74)\end{array}$ & $\begin{array}{l}-0.087^{* * *} \\
(-2.72)\end{array}$ & $\begin{array}{l}-0.087^{* *} \\
(-2.73)\end{array}$ & $\begin{array}{l}-0.087^{* *} \\
(-2.74)\end{array}$ \\
\hline Obse & ons & & 1268 & 1268 & 1268 & 1268 & 1268 & 1268 & 1268 & 1268 & 1268 \\
\hline Adju & R-squared & & 0.44 & 0.44 & 0.44 & 0.44 & 0.44 & 0.44 & 0.45 & 0.44 & 0.45 \\
\hline
\end{tabular}

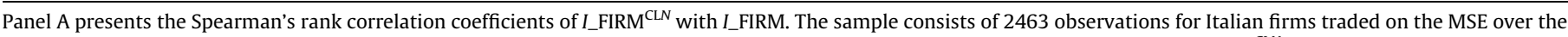

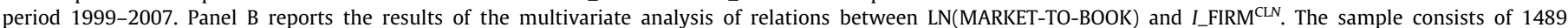

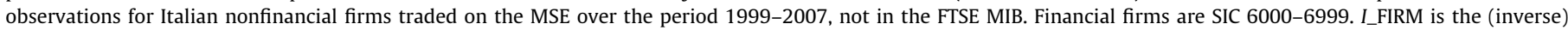

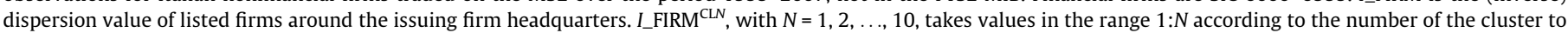

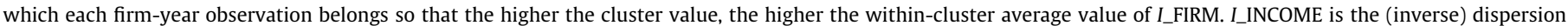

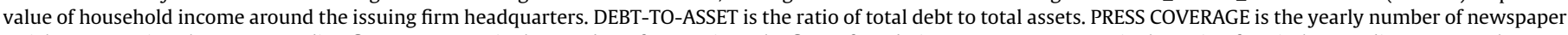

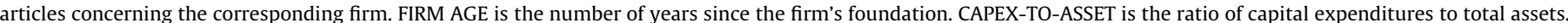

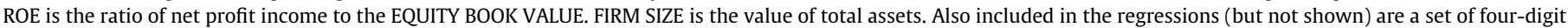

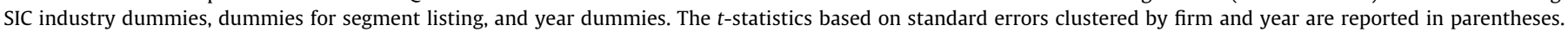

* Statistical significance at the $10 \%$ level.

** Statistical significance at the 5\% level.

**** Statistical significance at the $1 \%$ level.

How to determine the optimal number of clusters is a debated and as yet unsolved issue in the pertinent literature (e.g., Milligan and Cooper, 1985; Gordon, 1999). We address this issue empirically. First, we cluster observations upon I_FIRM and impose a stopping number $N$ equal to 10 in the hierarchical algorithm to reduce the computational burden of the analysis. Values of $N$ equal to 20,30 , or 40 do not change outcomes. Second, consistent with the panel structure of our data set, we perform cluster analysis on a yearly basis. Therefore, from clustering, we obtain a set of 10 clustered variables, designated I_FIRM YEAR $_{\mathrm{YEA}}^{\mathrm{C}}$ with YEAR $=1999$, 2000, .., 2007 and $N=1,2, \ldots, 10$. The generic variable $I_{-}$FIRM $_{\mathrm{YFAR}}^{\mathrm{C} N}$ is defined only in the respective YEAR and assumes values in the range $1-N$ depending on the number of clusters in which the observations have been split. Third, for each of the 90 $I_{-}$FIRM $_{\mathrm{YEAR}}^{\mathrm{CLN}}$ variables obtained from clustering, we rank and re-code within-variable clusters in ascending order according to the 
within-cluster average value of I_FIRM. This leads to a new set of 90 variables, where the generic variable $I_{-}$FIRM $_{\mathrm{YEAR}}^{\mathrm{CLN}}$ is identical to the corresponding I_FIRM $\mathrm{YEAR}_{\mathrm{YEN}}^{\mathrm{CLN}}$ except for the fact that it assumes values from 1 to $N$, and the higher the cluster value is, the higher the within-cluster average value of I_FIRM. Fourth, for each $N=1$, $2, \ldots, 10$, by matching over YEAR the $I_{-}$FIRM $_{\mathrm{YEAR}}^{\mathrm{CLN}}$ variables, we obtain 10 clustered versions of I_FIRM, designated I_FIRM ${ }^{\mathrm{CLN}}$. $I_{-}$FIRM $^{\mathrm{CLN}}$ is defined for all sampled observations, takes value in range $1-N$, and indicates the number of the cluster to which each observation belongs. In addition, clusters are ranked in ascending order of I_FIRM. Finally, we determine the optimal number of clusters and hence the optimal replacement for I_FIRM by investigating the pattern of (i) the correlations of I_FIRM with I_FIRM ${ }^{\mathrm{CLN}}$ variables and (ii) the statistical significance of the relations between each of the I_FIRM ${ }^{\mathrm{CLN}}$ variables and MARKET-TO-BOOK. To this end, we re-run Eq. (1) using each of the I_FIRM ${ }^{\mathrm{CLN}}$ variables instead of I_FIRM. Therefore, we run the following set of regressions:

$$
\begin{aligned}
L N(\text { MARKET }- \text { TO }- \text { BOOK })_{i, t}= & \delta_{0}+\delta_{N} * I_{-} \text {FIRM }_{\mathrm{i}, \mathrm{t}}^{\mathrm{CLN}} \\
& +\delta_{11} * I_{\mathrm{INCOME}}+\delta * \text { Controls }_{i, t} \\
& +\varepsilon_{i, t} \text { for } N=1,2, \ldots, 10
\end{aligned}
$$

We find that the optimal variable to replace I_FIRM is the fourclustered-based, i.e., I_FIRM ${ }^{\mathrm{CL} 4}$ (henceforth I_FIRM $^{\mathrm{CL}}$ ). The results of this selection process are reported in Table B.1.

As seen from Panel A of Table B.1, among the I_FIRM ${ }^{\mathrm{CLN}}$ variables, I_FIRM ${ }^{\mathrm{CL}}$ has the highest correlation (0.9411) with I_FIRM. Furthermore, we find that I_FIRM ${ }^{\mathrm{CL}}$ exhibits the most similar pattern to I_FIRM in explaining the MARKET-TO-BOOK. The coefficient on I_FIRM ${ }^{\mathrm{CL}}$ is negative and statistically significant: $\delta_{4}=-0.055, p$-value $<0.05$. More importantly, compared with the coefficients on I_FIRM ${ }^{\mathrm{CLN}}$ variables, $\delta_{4}$ is the closest in magnitude to $\gamma_{1}$, which is the estimated coefficient using I_FIRM (Table 3, Model 6: $\gamma_{1}=-0.068, p$-value $\left.<0.01\right)$. As conclusive evidence, we also test whether $\gamma_{1}=\delta_{4}$; ultimately, the null hypothesis is not rejected $\left(\chi^{2}\right.$-test $=0.94, p$-value $\left.=0.33\right)$.

\section{References}

Aabo, T., Pantzalis, C., Sørensen, M.S., 2013. Game hoarding in Europe: stock-price consequences of local bias? European Journal of Finance 19, 318-335.

Achleitner, A.-K., Betzer, A., Goergen, M., Hinterramskogler, B., 2013. Private equity acquisitions of continental European firms: the impact of ownership and control on the likelihood of being taken private. European Financial Management 19, 72-107.

Aggarwal, R., Prabhala, N.R., Puri, M., 2002. Institutional allocation in initial public offerings: empirical evidence. Journal of Finance 57, 1421-1442.

Anderberg, M.R., 1973. Cluster Analysis for Applications. Academic Press, New York.

Arena, M.P., Dewally, M., 2012. Firm location and corporate debt. Journal of Banking and Finance 36, 1079-1092.

Audretsch, D.B., Feldman, M.P., 1996. R\&D spillovers and the geography of innovation and production. American Economic Review 86, 630-640.

Bagella, M., Becchetti, L., Carpentieri, A., 2000. 'The first shall be last'. Size and value strategy premia at the London Stock Exchange. Journal of Banking and Finance 24, 893-919.

Baran, L.C., King, T.H.-D., 2010. Going private transactions, bondholder returns, and wealth transfer effects. Journal of Banking and Finance 34, 1856-1872.

Birz, G., Lott Jr., J.R., 2011. The effect of macroeconomic news on stock returns: new evidence from newspaper coverage. Journal of Banking and Finance 35, 27912800.

Boubakri, N., Cosset, J.-C., Debab, N., Valéry, P., 2013. Privatization and globalization: an empirical analysis. Journal of Banking and Finance 37, 18981914.

Braun, M., Larrain, B., 2009. Do IPOs affect the prices of other stocks? Evidence from emerging markets. Review of Financial Studies 22, 1505-1544.

Brisker, E.R., Colak, G., Peterson, D.R., 2013. Changes in cash holdings around the S\&P 500 additions. Journal of Banking and Finance 37, 1787-1807.

Cassia, L., Giudici, G., Paleari, S., Redondi, R., 2004. IPO underpricing in Italy. Applied Financial Economics 14, 179-194.

Chan, L.K., Lakonishok, J., Sougiannis, T., 2001. The stock market valuation of research and development expenditures. Journal of Finance 56, 2431-2456.

Chemmanur, T.J., He, S., Nandy, D.K., 2010. The going-public decision and the product market. Review of Financial Studies 23, 1855-1908.
Chou, P.-H., Ho, P.-H., Ko, K.-C., 2012. Do industries matter in explaining stock returns and asset-pricing anomalies? Journal of Banking and Finance 36, 355370.

Chua, C.T., Eun, C.S., Lai, S., 2007. Corporate valuation around the world: the effects of governance, growth, and openness. Journal of Banking and Finance 31, 35-56.

Colaco, H.M.J., Ghosh, C., Knopf, J.D., Teall, J.L., 2009. IPOs, clustering, indirect learning and filing independently. Journal of Banking and Finance 33, 2070-2079.

Coval, J.D., Moskowitz, T.J., 1999. Home bias at home: local equity preference in domestic portfolios. Journal of Finance 54, 2045-2073.

Coval, J.D., Moskowitz, T.J., 2001. The geography of investment: informed trading and asset prices. Journal of Political Economy 109, 811-841.

Croci, E., Del Giudice, A., 2014. Delistings, controlling shareholders and firm performance in Europe. European Financial Management 20, 374-405.

Day, W.H., Edelsbrunner, H., 1984. Efficient algorithms for agglomerative hierarchical clustering methods. Journal of Classification 1, 7-24.

Detemple, J., Garcia, R., Rindisbacher, M., 2005. Intertemporal asset allocation: a comparison of methods. Journal of Banking and Finance 29, 2821-2848.

Enright, M., 2003. Regional clusters: what we know and what we should know. In: Brocker, J., Dohse, D., Soltwedel, R. (Eds.), Innovation Clusters and Interregional Competition. Springer-Verlag, Berlin Heidelberg.

Everitt, B.S., Landau, S., Leese, M., Stahl, D., 2011. Cluster Analysis. Wiley, New York.

Faccio, M., Lang, L.H., 2002. The ultimate ownership of western European corporations. Journal of Financial Economics 65, 365-395.

Farinelli, S., Ferreira, M., Rossello, D., Thoeny, M., Tibiletti, L., 2008. Beyond sharpe ratio: optimal asset allocation using different performance ratios. Journal of Banking and Finance 32, 2057-2063.

Fidrmuc, J.P., Palandri, A., Roosenboom, P., Van Dijk, D., 2013. When do managers seek private equity backing in public-to-private transactions? Review of Finance 17, 1099-1139.

Gao, W., Ng, L., Wang, Q., 2008. Does geographic dispersion affect firm valuation? Journal of Corporate Finance 14, 674-687.

García, D., Norli, Ø., 2012. Geographic dispersion and stock returns. Journal of Financial Economics 106, 547-565.

Gomelyuk, V.E., Shchetkov, S.Y., 1999. Small-scale spatial structure of two flatfish species, in Peter the Great Bay, Sea of Japan. Journal of the Marine Biological Association of the United Kingdom 79, 509-520.

Gordon, A.D., 1999. Classification. Chapman Hall/CRC, Boca Raton, Florida.

Grinblatt, M., Keloharju, M., 2001. How distance, language, and culture influence stockholdings and trades. Journal of Finance 56, 1053-1073.

Guiso, L., Sapienza, P., Zingales, L., 2004. Does local financial development matter? Quarterly Journal of Economics 119, 929-969.

Gygax, A.F., Otchere, I., 2010. Index composition changes and the cost of incumbency. Journal of Banking and Finance 34, 2500-2509.

Hanley, K.W., 1993. The underpricing of initial public offerings and the partial adjustment phenomenon. Journal of Financial Economics 34, 231-250.

Hasan, I., Koetter, M., Wedow, M., 2009. Regional growth and finance in Europe: is there a quality effect of bank efficiency? Journal of Banking and Finance 33, 1446-1453.

Heckman, J.J., 1979. Sample selection bias as a specification error. Econometrica 47 $153-161$.

Hong, H., Kubik, J.D., Stein, J.C., 2008. The only game in town: stock-price consequences of local bias. Journal of Financial Economics 90, 20-37.

Hsu, H.-C., Reed, A.V., Rocholl, J., 2010. The new game in town: competitive effects of IPOs. Journal of Finance 65, 495-528.

Ivković, Z., Weisbenner, S., 2005. Local does as local is: information content of the geography of individual investors' common stock investments. Journal of Finance 60, 267-306.

Johnson, R.B., Zimmer, W.J., 1985. A more powerful test for dispersion using distance measurements. Ecology 66, 1669-1675.

Karlsson, A., Nordén, L., 2007. Home sweet home: home bias and international diversification among individual investors. Journal of Banking and Finance 31 317-333.

Kaufman, L., Rousseeuw, P.J., 1990. Finding Groups in Data: An Introduction to Cluster Analysis. Wiley, New York.

Keloharju, M., Kulp, K., 1996. Market-to-book ratios, equity retention, and management ownership in Finnish initial public offerings. Journal of Banking and Finance 20, 1583-1599.

Korniotis, G.M., Kumar, A., 2013. State-level business cycles and local return predictability. Journal of Finance 68, 1037-1096.

Krugman, P.R., 1991. Increasing returns and economic geography. Journal of Political Economy 99, 483-499.

Landier, A., Nair, V.B., Wulf, J., 2009. Trade-offs in staying close: corporate decision making and geographic dispersion. Review of Financial Studies 22, 1119-1148.

Lee, S.-H., Bardunias, P., Su, N.-Y., 2006. Food encounter rates of simulated termite tunnels with variable food size/distribution pattern and tunnel branch length. Journal of Theoretical Biology 243, 493-500.

Ljungqvist, A.P., Wilhelm, W.J., 2003. IPO pricing in the dot-com bubble. Journal of Finance 58, 723-752.

Loughran, T., 2008. The impact of firm location on equity issuance. Financial Management 37, 1-21.

Loughran, T., Ritter, J.R., 2004. Why has IPO underpricing changed over time? Financial Management 33, 5-37.

Loughran, T., Schultz, P., 2005. Liquidity: urban versus rural firms. Journal of Financial Economics 78, 341-374. 
Lowry, M., Officer, M.S., Schwert, G.W., 2010. The variability of IPO initial returns. Journal of Finance 65, 425-465.

Marshall, A., 1920. Principles of Economics. Macmillan, London.

Megginson, W.L., Weiss, K.A., 1991. Venture capitalist certification in initial public offerings. Journal of Finance 46, 879-903.

Milligan, G.W., Cooper, M.C., 1985. An examination of procedures for determining the number of clusters in a data set. Psychometrika 50, 159-179.

Pagano, M., Panetta, F., Zingales, L., 1998. Why do companies go public? An empirical analysis. Journal of Finance 53, 27-64.

Pazzaglia, F., Mengoli, S., Sapienza, E., 2013. Earnings quality in acquired and nonacquired family firms: a socioemotional wealth perspective. Family Business Review 26, 374-386.

Petersen, M.A., 2009. Estimating standard errors in finance panel data sets: comparing approaches. Review of Financial Studies 22, 435-480.

Pirinsky, C., Wang, Q., 2006. Does corporate headquarters location matter for stock returns? Journal of Finance 61, 1991-2015.
Renneboog, L., Simons, T., 2005. Public-to-private transactions: LBOs, MBOs, MBIs and IBOs, working paper.

Renneboog, L., Simons, T., Wright, M., 2007. Why do public firms go private in the UK? The impact of private equity investors, incentive realignment and undervaluation. Journal of Corporate Finance 13, 591-628.

Ritter, J.R., Welch, I., 2002. A review of IPO activity, pricing, and allocations. Journal of Finance 57, 1795-1828.

Rosenthal, S.S., Strange, W.C., 2004. Evidence on the nature and sources of agglomeration economies. In: Henderson, J.V., Thisse, J.F.E. (Eds.), Handbook of Regional and Urban Economics, vol. 4. Elsevier.

Tse, Y., Devos, E., 2004. Trading costs, investor recognition and market response: an analysis of firms that move from the Amex (Nasdaq) to Nasdaq (Amex). Journal of Banking and Finance 28, 63-83.

Van Dijk, M.A., 2011. Is size dead? A review of the size effect in equity returns. Journal of Banking and Finance 35, 3263-3274.

Zhu, N., 2003. The local bias of individual investors, working paper. 